
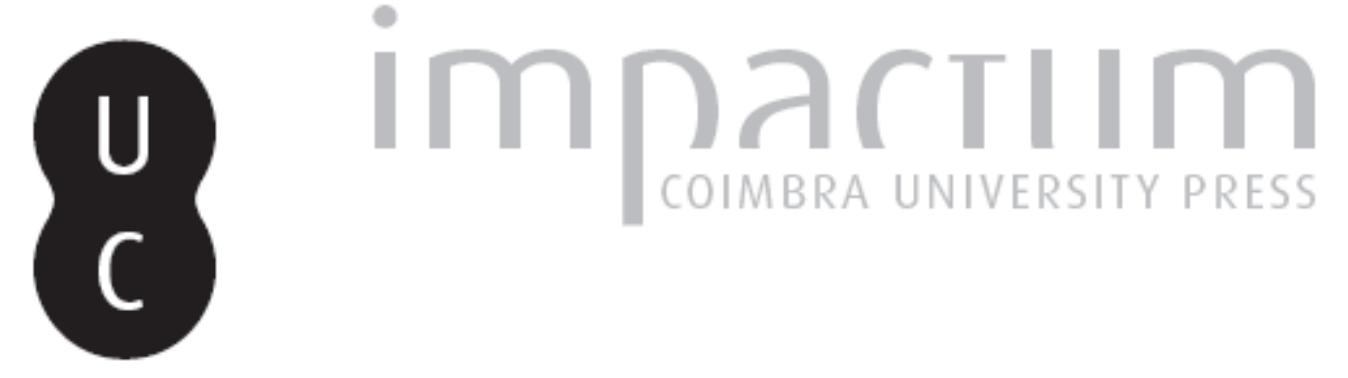

\title{
O neo-iluminismo filosófico de António Sérgio
}

\section{Autor(es): $\quad$ Pereira, Miguel Baptista}

Publicado por: Imprensa da Universidade de Coimbra

URL persistente:

URI:http://hdl.handle.net/10316.2/45040

DOI:

DOI:https://doi.org/10.14195/2183-8925_5-1_1

Accessed : $\quad$ 26-Apr-2023 13:46:08

A navegação consulta e descarregamento dos títulos inseridos nas Bibliotecas Digitais UC Digitalis, UC Pombalina e UC Impactum, pressupõem a aceitação plena e sem reservas dos Termos e Condições de Uso destas Bibliotecas Digitais, disponíveis em https://digitalis.uc.pt/pt-pt/termos.

Conforme exposto nos referidos Termos e Condições de Uso, o descarregamento de títulos de acesso restrito requer uma licença válida de autorização devendo o utilizador aceder ao(s) documento(s) a partir de um endereço de IP da instituição detentora da supramencionada licença.

Ao utilizador é apenas permitido o descarregamento para uso pessoal, pelo que o emprego do(s) título(s) descarregado(s) para outro fim, designadamente comercial, carece de autorização do respetivo autor ou editor da obra.

Na medida em que todas as obras da UC Digitalis se encontram protegidas pelo Código do Direito de Autor e Direitos Conexos e demais legislação aplicável, toda a cópia, parcial ou total, deste documento, nos casos em que é legalmente admitida, deverá conter ou fazer-se acompanhar por este aviso.

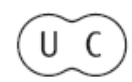




\section{REVISTA DE HISTÓRIA DAS IDEIAS 5}

\section{António Sérgio}

*

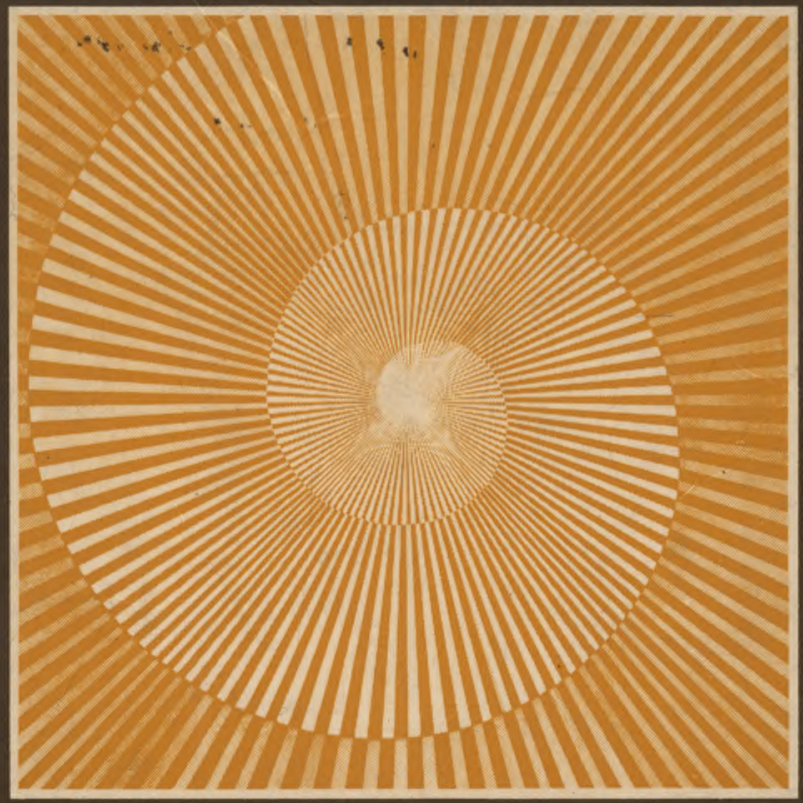

INSTITUTO DE HISTÓRIA E TEORIA DAS IDEIAS FACULDADE DE LETRAS 


\title{
O NEO-ILUMINISMO FILOSÓFICO DE ANTÓNIO SÉRGIO
}

\begin{abstract}
A figura de António Sérgio é demasiado rica e polivalente para se confinar à estreiteza de um título, como as possibilidades de mundo abertas pela sua obra se descobrem não no isolamento de algumas invariantes mas na convergência de linhas de sentido exploradas numa investigação interdisciplinar. Comemorar o primeiro centenário de A. Sérgio é recordar a densidade de problemas comuns, realizando, por viva apropriação, a força etimológica deste verbo. Neste empenho, cabe à reflexão filosófica interpretar o sentido profundo dos seus escritos longe das paixões de superfície, que dividem os homens, e dos egoísmos imediatos, que retalham amiúde a integridade de um património. Igualmente reconhecidos a Sérgio se devem confessar os cultores da teoria e da praxis política e social, os investigadores da cultura e da pedagogia, os defensores do estatuto científico da Teologia e do Cristianismo, os apegados à crítica da sociedade e da história ou os espíritos interrogativos, que preferem inteligentemente o gume da crítica à areia inconsistente da ingenuidade crédula. Particularmente, o historiador consciente, que, por treino de ofício ou intuição de autodidacta, se recuse, colorir, com um gongorismo ideológico, a difícil hermenêutica dos factos, não recusará participar no diálogo crítico sobre a realidade histórica portuguesa aberto pela ensaística de Sérgio. O historiador da educação, que não queira reduzir o seu munus ao que Sérgio classificou de "sabença» extrinsecista e irreflectida, sentir-se-á constrangido a pesquisar, para além da acta do banco de dados do computador, a
\end{abstract}

\footnotetext{
* Faculdade de Letras da Universidade de Coimbra.
} 
essência da educação num mundo, que se reclama do ideal da libertação. O teórico da literatura, que não iluda a essência do fenómeno literário com a floresta bibliográfica ou a diversão erudita, reconhecerá em Sérgio um convite à reflexão e à atitude crítica, que nos convença de que vale a pena pensar a literatura. Porém, o processo mais anti-sergiano de investigar ou de ensinar é prender-se do fetichismo do texto alheio, glosando indefinidamente, em ruminações estéreis, a produção intelectual de outrem, comentando e repetindo o já dito, frustando os alunos ou os leitores, sem consciência dos problemas, que jazem silenciosos sob a roupagem doxográfica ou o úbere rodapé dos pormenores, curiosidades e citações, que são a vulgar moeda de troca do academismo pelo real alheamento dos problemas. Vinda do exterior, a voz de Sérgio é incómoda para a anquilose académica e uma censura ao seu bruxuleante espírito fílosófico. Também à Teologia e ao seu conceito de redenção é dirigido o repto de Sérgio, saído de uma leitura secularizadora do Cristianismo e alimentado pelo ideal de uma praxis crítica e libertadora do homem histórico concreto.

Esta reflexão sobre o neo-iluminismo de Sérgio nasceu do confronto de dois ideais: o do socialismo libertário, animado de um conceito de trabalho solidário e fraterno e o da razão crítica, retomada do Iluminismo e inserida na vida histórica do séc. XX. Os temas modernos da solidariedade, da fraternidade e do trabalho são preferidos como regiões onde habita o pensamento social de Sérgio, o que permite situá-lo sem a obrigatoriedade de usar etiquetas de escola e, simultaneamente, franquear uma via de acesso ao seu pensamento, que não fosse um caminho na floresta. A razão crítica, dessubjectivada e intersubjectiva, ética e activa por essência, universal e concreta, emancipada e socialmente religada, é a razão do socialismo cooperativista, solidária, fraterna e laboriosa. Fica assim jutificada a ordenação interna deste artigo: ao apontamento introdutório sobre os conceitos de solidariedade, fraternidade e trabalho, segue-se a análise da crítica à autoridade, da actividade super-coisista, da dimensão ética e da secularização, que dão jus a falar-se de um neo-iluminismo em A. Sérgio e são as linhas do seu modelo interpretativo do socialismo.

I. A ideia sergiana de uma sociedade, que, por si mesma, se emancipasse sem recurso ao poder, a não ser provisoriamente e numa intenção de serviço, evoca imediatamente o conceito de solidariedade e o papel por ele exercido no ideal de sociedade desde o séc. XIX. Ao contrário do que muitas 
vezes se afirma, a palavra 'solidariedade' não é qualquer termo do latim clássico ou medieval nem tão-pouco uma criação da doutrina social cristã mas foi introduzido pela primeira vez na filosofia pelo socialista P. Leroux, segundo o seu próprio testemunho, e só depois penetrou na linguagem religiosa. Vinda dos legistas, 'solidariedade' significou aquela relação jurídica em que cada devedor se responsabiliza pela totalidade (in solidum) de uma determinada quantia, considerando-se os co-devedores do mesmo modo igualmente responsáveis. O sentido fundamental de solidariedade exige, portanto, que um se responsabilize por todos e todos por um, não em virtude de uma quantidade em numerário mas porque estão em causa valores do homem. Leroux pretendeu substituir o amor cristão, em que não via qualquer relação com a liberdade humana, pela solidariedade humana, do mesmo modo que, em vez do Deus do arbítrio e mau pregado pela Igreja, opressor da liberdade e fomentador da renúncia e do desprezo de si mesmo, escogitou um Deus, que fosse vida imanente à humanidade, seu princípio unificador e raiz da solidariedade ou lei universal dos homens $\left({ }^{1}\right)$. Depois de A. Comte se ter proposto despertar «o sentimento interior da solidariedade social» $\left({ }^{2}\right)$, 'solidariedade' tornou-se um conceito básico da filosofia social francesa do séc. XIX $\left({ }^{3}\right)$, com especial destaque para a doutrina de $\mathrm{Ch}$. Fourier, principal obreiro da divulgação deste conceito $\left({ }^{4}\right)$. A articulação entre solidariedade, moralidade e liberdade colige-se da convergência da afirmação de E. Durkheim de que é moral «tudo o que resulta da solidariedade» $\left({ }^{5}\right)$ e da tese, inversamente fundamentada, de Hegel de que é moralmente bom tudo o que torna possível e fomenta o reconhecimento recíproco de todos os homens, distinguido-se, deste modo, a liberdade do arbítrio ${ }^{6}{ }^{6}$. Na concepção moral da liberdade dominou tradicionalmente

0) L. Oeing-Hanoff, «Freheit und Solidaritaet, Zur Kritik des liber alistischen und sozialistischen Freiheitsverstaendnisses» in: G. Hoeltner, Hrsg., Personale Freiheit und pluralistische Gesellschaft (Wien-Freiburg-Basel 1981) 9.

(2) A. Comte, Discours sur Vesprit positiv, hrsg. I. Fetscher, 154, cit. por L. Oeing-Hannhof, ob. cït., $\mathbf{1 0}^{6}$.

C) L Oeing-Hanhoff, ob. cit., 10 .

$\left(^{4}\right)$ Cr. H. Renaud, Solidarité. Vue synthétique de la doctrine de Charles Fourier (Paris 1842). Esta obra teve mais de sete edições até ao fim do século. Cf. A. E. Bestor, "The Evolution of the Socialist Vocabulary», Journal of the History of Ideas 9 (1948) 273.

(5) E. Durkheim, Division du Travail social ${ }^{4}$ (Paris 1923) 394.

(6) Cf. F. Grégoire, Etudes Hégéliennes, Les Points capitaux du Système (Louvain-Paris 1958) 31-39. 
a dimensão individual e, por isso, a descoberta da alteridade na essência da liberdade revela-se um avanço extraordinário na consciência europeia. Na verdade, o esquema sujeito-objecto, em sentido realista ou idealista, é sempre egologicamente orientado, desde o ideal grego de «autarquia» ao «cogito, ergo sum» de Descartes ou à antítese entre $\mathrm{Eu}$ e não-Eu, para Fichte uma condição transcendental da nossa consciência e um pressuposto último de todo o nosso conhecimento ${ }^{7}$ ). Segundo este modelo egocêntrico, o sujeito domina o objecto não só em sentido lógico mas também ontológico, confluindo na mesma actividade a subjectividade, o amor de si mesmo e a vontade de poder. Portanto, toda a realidade, desde a natureza à existência humana, é pensada a partir da estrutura egóide da consciência e o agir humano é condicionado pela prioridade deste tipo de saber. Naturalmente, uma ética construída neste horizonte apresenta os traços egológicos da origem, assinaláveis no pensamento grego, medieval e moderno $\left({ }^{8}\right)$.

Sob o nome de «solidarismo», a doutrina social católica divulgou, no início do presente século, uma concepção crítica do individualismo e do colectivismo mas as categorias aristotélicas de substância e de acidente, de que se serviu, não eram meios conceptuais apropriados à captação da relação essencial e não acidental do indivíduo à comunidade. Além do fracasso do modelo coisista de substância, o conceito grego de liberdade como «autarquia», que sobrevive no individualismo europeu, restringe-se ao pleno «bastar-se a si mesmo», à identidade que descansa em si mesma e ao «ser interior a si mesmo» $\left({ }^{9}\right)$, não podendo de modo algum traduzir a liberdade entendida na essencial relacionalidade, que a dimensão originária de solidariedade impõe. Este problema não foi alheio à reflexão de Max Scheler, como comprova a sua visão da relação dialéctica, intrínseca ao ser da pessoa, «que é tão originariamente ser-para-si como ser-com-outrem», e do "princípio da solidariedade moral» $\left({ }^{10}\right)$. A afirmação da relação

O J. G. Fichte, «Grundlage der fesammten Wissenschaftslehre» in: Werke 1793-1795, hrsg. von R. Lauth/H. Jakob (Stuttgart-Bad Cannstatt 1965) $\$ 1, \S 2,255-267$.

$\left({ }^{8}\right)$ A. Edmaier, Dialogische Ethik, Perspektiven, Prinzipien (Kevelaer 1969) 11-18.

O Cf. H. Kraemer, «Die Grundlegung des Freiheitsbegriffs in der Antike» in: J. SIMON, Hrsg., Freiheit. Theoretische und praktische Aspekte des Problems (Muenchen 1977) 258 ss.

(ii) M. Scheller, Vom Ewigen im Menschen ${ }^{5}$ (Bern-Muenchen 1954) 371, 375 ss. 
com a exclusão da moralidade não basta para constituir a solidariedade, como prova $O$ Ser e o Nada de J.-P. Sartre, em que o «ser-para-outrem», privado de qualquer dimensão ética, é objectivador e dominador ou objectivado e dominado, em situação de luta e de conflito, sem qualquer possibilidade de reconhecimento mútuo $\mathrm{O}^{1}$ ).

$\mathrm{Na}$ sua luta contra a ideia de Estado, o anarquismo procurou acolhedor refúgio no conceito de solidariedade, desde P.-J. Proudhon a E. Fromm, que deduziu a solidariedade da experiência mística da unidade da realidade, onde se enraizaria a comunhão dos homens entre si $\left({ }^{12}\right)$. A solidariedade com todos os homens foi restringida pelo Marxismo-Leninismo, em virtude da exclusão dos inimigos do comunismo, à «solidariedade fraternal com os trabalhadores de todos os países» $\left({ }^{13}\right)$. Por isso, foi através de F. Lassalle e não de Marx que a palavra «solidariedade» se tomou familiar no movimento operário alemão para exprimir a complementaridade das forças individuais pela comunidade e reciprocidade de interesses, sob o imperativo do conceito hegeliano de liberdade, como fim supremo do Estado, que é uma «ordem moral» $\left({ }^{14}\right)$. Solidariedade, liberdade e moralidade são pensadas na sua pertença mútua e indestrutível vinculação.

A autonomia, que torna o homem individual senhor dos bens fundamentais da «liberdade, vida e propriedade», formulada por J. Locke $\left({ }^{15}\right)$, foi depois recebida em diversas declarações dos direitos do homem $\left({ }^{16}\right)$. Esta autonomia, porém, foi convertida por Kant na lei moral presente em cada um de nós, exigente e imperativa, acima da natureza e das disposições inatas e que torna o homem digno e livre. Sem um acto de autonomia moral, o homem permanece abaixo do seu nível, não se humaniza; com ele, atinge a universalidade incondicional da sua acção e nesta os outros homens, coafirmados como fins e respeitados na sua intangível dignidade e li-

(") J.-P. Sartre, L'Étre et le Néant. Essai d'Oontologie phénoménologique (Paris 1976) 265-349, 413-481.

$\left(\begin{array}{l}12 \\ )\end{array}\right.$ L. Oeing-Hanhoff, oh. cit., 10-11.

(13) Cf. «Programm der kommunistischen Partei der Sowjetunion (1961)» in: L. W. Gasteyger, Hrsg., Perspektiven der sowjetischen Politik. Der XXII Parteitag und das neue Parteiprogramm. Eine Dokumentation (1962) cit. por L. Oeing-Hanhoff, ob. cit., 11.

$\left({ }^{14}\right)$ L. Oeing-Hanhoff, ob. cit., 11.

$\left.\mathbf{O}^{5}\right)$ J. Locke, Two Treatises of Governement, a critical edition with Introduction and Notes by Peter Laslett ${ }^{2}$ (Cambridge 1967) 368.

(“" ) A. Baruzzi, Europaeisches 'Menschenbild' und das Grundgesetz fuer die Bundesrepublik Deutschland (Freiburg-Muenchen 1979) 13-14. 
berdade $\left({ }^{17}\right)$. Este sentido do valor incondicionado da dignidade alheia, presente na autonomia do eu, permaneceu estranho à concepção de Estado liberal, que apenas garantia e protegia os direitos da liberdade, vida e propriedade dos indivíduos isolados, com total olvido da relação de solidariedade, que os mesmos indivíduos vincula. Hegel concebeu o estado de direito como a condição de possibilidade da realidade da liberdade concreta $\left({ }^{18}\right)$, isto é, toda a ordem jurídica, com os direitos humanos e as liberdades do cidadão, pressupõe o estado como garantia de realização. A libertação de «bellum omnium contra omnes», da condição pré-civil da natureza é a constituição de uma ordem jurídica assegurada pelo poder estatal e só nesta ordem é possível a liberdade moral e responsável. A liberdade concreta identificada com a ordem jurídica não é simples auto-determinação, que pode ser arbitrária, mas recíproco reconhecimento dos indivíduos, pois cada um só é livre na medida em que afirmar a liberdade dos outros e for pelos outros reconhecido como livre $\left({ }^{19}\right)$. Querer a liberdade é reconhecer nos outros a mesma liberdade que eles reconhecem em nós, é responder solidariamente pelo valor fundamental comum da liberdade. Esta vontade intersubjectiva de liberdade ou solidariedade concreta implica, na sua realização, a mediação da moralidade, do direito e do estado. Decidir-se pela liberdade é prover com outros à manutenção e incremento da liberdade de todos, mediante a criação do estado como instituição universal da liberdade. Daí, a dupla face da liberdade hegeliana: exigência do estado como sua condição de possibilidade e solidariedade com todos os que se reconhecem mutuamente como livres. A solidariedade, porém, exige a eliminação do egoísmo e do apetite universal do lucro com a correcção de desigualdades sociais e é, como momento essencial da liberdade, o princípio ou o valor fundamental do estado $\left({ }^{20}\right)$. Mais do que a igualdade de todos perante a lei, a liberdade exige reconhecimento mútuo, segundo a terminologia de Hegel, ou solidariedade, na expressã̃o de Leroux, ou fraternidade, como propôs Proudhon $\left({ }^{21}\right)$. Esta li-

('1T) J. Schwartlaender, Der Mensch ist Person, Kants Lehre vom Menschen (Stuttgard-Berlin-Koel-Mainz 1968) 122-198.

${ }^{18}$ ) G. W. F. Hegel, Grundlinien der Philosophie des Rechts oder Naturrecht und Staatswissenschaft im Grundrisse, Mit Hegels engenhaendigen Notizen und den muendlichen Zusaetzen, hrsg., v. E. Moldenhauer-K. M. Michel (Frankfurt/M. 1970) 406-407.

( $\left.{ }^{19}\right)$ F. Grégoire, ob cit, 32-39, 57-61. bridge 1974) 176-184.

$C^{2 b}$ Sh. Avineri, HegeVs Theory of the Modern State (Cam-

(12) L. Oeing-Hanhoff, ob. cit., 14. 
berdade solidária e fraterna, pela relação de alteridade em que se empenha, é a que visa o universal concreto do país real, dado o fosso entre a igualdade abstracta e nominal perante a lei e a crueza da desigualdade real, cavado pelo conceito de liberdade do liberalismo.

Além da mediação pelo outro, o individualismo liberal ignorou, segundo Hegel, a historicidade da liberdade e, com ela, a mediação necessária das instituições históricas. A fórmula contida em muitas declarações dos direitos do homem de que o homem é, por natureza, livre, é recusada por Hegel em virtude da sua unilateralidade e corrigida no sentido de o homem ser, por natureza, livre em se tornar livre, isto é, em realizar a sua liberdade real através das instituições históricas, que a possibilitam $\left({ }^{22}\right)$.

Fica o acesso do homem à liberdade condicionado por todas as normas racionais de acção, que curam da liberdade de todos e a que Hegel chama a «liberdade objectiva» $\left({ }^{23}\right)$. Estas normas morais e jurídicas da «liberdade objectiva» são o meio pelo qual o indivíduo reconhece o outro e é por este reconhecido, isto é, são condições históricas de possibilidade da liberdade humana, em que o passado é já oferta de liberdade, cuja recusa torna culpável toda a menoridade mental, como se exprime Kant no seu escrito sobre o Iluminismo $\left({ }^{24}\right)$. Conotando substancialmente o reconhecimento fraterno universal dos homens instaurado pelo Cristianismo, a liberdade hegeliana é o incondicionado, é «o divino no homem»e, por isso, a entrada no reino da liberdade é um «renascimento no espírito divino» $\left({ }^{25}\right)$.

No sentido de «solidariedade» evoluiu historicamente outro conceito ocidental, velho de séculos, o de «fraternidade». De longas raízes nas corporações religiosas e seculares da sociedade cristã medieval, a união fraternal, organizada segundo estratos sociais para a prática comum de objectivos religiosos ou civis mas sempre dentro da observância da fé cristã, sofreu a crise da Modernidade, ao emancipar-se da fixação institucional de classe e ao reivindicar um liame entre

${ }^{(22)}$ G. W. F. Hegel, Grundlinien der Philosophie des Rechts

$\left.{ }^{(23}\right)$ Idem, ob. cit., 87-88, 399-402.

$\left.\mathrm{C}^{24}\right)$ I. Kant, «Beantwortung der Frage: Was ist Aufklaerung?» in: N. Hinske; Hrsg., Was ist Aufklaerung. Beitrage aus der Beninischen Montsschrift ${ }^{3}$ (Darmstadt 1981) 452.

lichen Geist» in:

$\left.{ }^{25}\right)$ L. Oeing-Hanhoff, «Freheit als Wiedergeburt im goett(Freiburg-Muenchen 1979) 254-281. 
os homens, distinto do seu estatuto de cristãos. Apesar de na 'Guerra dos Camponeses' de 1524/25 ter surgido na Alemanha um movimento de rurais, que compelia burgueses e cavaleiros a entrar na mesma corporação com fins sociais, rompendo as fronteiras de classes $\left({ }^{26}\right)$, o horizonte teológico, em que se desenhou esta inovação, está ainda distante da secularização do culto do irmão praticado nas lojas secretas da Maçonaria no séc. XVIII. E de irmão o «nome que se dão uns aos outros os mações de todos os graus. $\mathrm{O}$ doce nome de irmão exprime suficientemente os deveres do mação para com outro mação» $\left({ }^{27}\right)$. Este culto do irmão foi dissociado de qualquer vinculação confessional ou eclesial e abrangia, para os mações e pietistas, além dos correligionários, o homem enquanto homem, embora com fundamentações diferentes, pois o pietista visava pela prática do amor fraterno cumprir o mandamento cristão do amor e o mação deduzia essa mesma prática simplesmente da lei moral $\left({ }^{28}\right)$. A união universal dos homens, super-cristã e directamente fundada na ideia de humanidade, foi o objectivo da filosofia iluminista da história e, sob o aspecto revolucionário, apareceu inscrita no conhecido lema da Revolução Francesa. Nas «Sociedades Fraternas» então fundadas, o ideal de «fraternidade» designava o programa político de extinção das diferenças de classe até então vigentes e, com a introdução do regime republicano, equacionou-se assim a nova realidade: «Veuillez.... proclamer la République, proclamez donc la fraternité, ce n'est qu'une même chose» $\left({ }^{2}\right)$, mau grado a distância, que da prática separou este ideal generoso. Na revolução de 1848, de novo a «fraternidade» foi lábaro de combate e, pela primeira vez, apareceu no preâmbulo de um texto constitucional, ao lado de liberdade e igualdade $\left({ }^{30}\right)$.

$\mathrm{C}^{26}$ ) W. Schieder, «Bruederlichkeit, Bruderschaft, Bruederschaft, Verbruederung, Bruderliebe» in: O. Brunner-W. Conze R. Koselleck, Hrsg., Geschichtliche Grundbergrif je, Historisches Lexicon zur politisch-sozialen Sprache in Deutschland, Bd. I, A-D, (Stuttgart 1974) 562-563.

${ }_{\left({ }^{27}\right)}$ Ch.-François-Nicolas Quentin, Dictionaire maçonnique ou Recueil d'esquisses de toutes les parties de l'édifice connu sous le nom de Maçonnerie (Paris 1825) 58.

${ }^{(28)}$ O primeiro artigo da constituição maçónica começa pela frase: "A Mason is oblig'd by his Tenure to obey Moral Law». B. Fay, La Franc-Maçonnerie et la Révolution intellectuelle du XVIII ${ }^{e}$ Siècle (Paris 1935) 273.

(29) A. Mathiez, La Révolution Française, T. $I^{7}$ (Paris 1940) 90, cit. por W. Chiedler, ob. cit., 566.

(30) W. Chiedler, ob. cit, 572. 
Para o movimento operário e logo desde as suas origens, «fraternidade» tornou-se um lema da emancipação social em que se foi forjando a consciência do operário. De início, a palavra tinha entre os trabalhadores uma acentuação predominantemente religiosa, pois a esperança numa igualdade social era identificada com o conteúdo da mensagem cristã e só muito lentamente se foi eclipsando esta dimensão de sentido no movimento operário alemão $\left({ }^{31}\right)$. «Fraternidade» tornou-se finalmente um conceito moral e social exclusivo dos trabalhadores, que, à sombra deste ideal, multiplicaram as suas associações. Em 1845, F. Engels, ao escrever sobre uma festa de confraternização de operários de diferentes nacionalidades, exclui deste encontro super-nacional a burguesia, porque incapaz de superar os seus interesses sempre confundidos com a nacionalidade e a sociedade estabelecida: «só os proletários podem negar a nacionalidade, só o proletariado que desperta, pode fazer que as diferentes nações confraternizem» $\left({ }^{32}\right)$. O conceito de fraternidade é desvinculado por Engels e Marx da sua origem burguesa e transformado no conceito de solidariedade do movimento operário, já dentro do espírito da luta de classes $\left({ }^{33}\right)$. Na verdade, com a progressiva formulação da teoria da luta de classes, o conceito de fraternidade tornou-se incómodo, sendo em 1846 alvo da crítica mordaz de Engels $\left({ }^{34}\right)$ e, em 1847, a expressão antiga «todos os homens são irmãos» foi substituída pelo grito "Proletários de todos os países, uni-vos!». Referindo-se à revolução de 1848, Marx identificou a fraternidade de classes em luta, a união impossível dos interesses da burguesia e dos do proletariado com a guerra civil $\left({ }^{35}\right)$ e, dois anos mais tarde, considerou a fraternidade uma eliminação ou abstracção da luta de classes ou a sua concertação sentimental e fantasiosa $\left({ }^{36}\right)$. «Fraternidade» converteu-se no conceito oposto a «luta de classes» sobretudo pelo espírito superador das oposições e pela síntese harmoniosa, que veiculava, e continuou viva, como princípio humanitário, em movimentos operários europeus ainda nos anos 70, na inten-

(31) Idem, ob. dt., 575-576.

(32) F. Engels, «Das Fest der Nationen in London» in: K. Marx-F. Engels, Werke, Bd. II (Berlin 1974) 614.

${ }^{(33)}$ Idem, ob. cit., $\mathbf{6 2 1}$.

( ${ }^{34}$ Idem, «Engels an das kommunistische Korrespondez-Komitee in Bruessel» in: K. Marx-F. Engels, Bd. 27 (Berlin 1973) 63.

$\left({ }^{35}\right)$ K. Marx, «Die Junirevolution, Neue Rheinische Zeitung, 29.6.1848» in: K. Marx-F. Engels, Werke, $B d$. V, (Berlin 1959) 134.

$\left({ }^{3<s}\right)$ Idem, «Die Klassenkämpfe in Frankreich 1848 bis 1850» in: K. Marx-F .Engels, Werke, Bd. VII, (1960) 21. 
ção de unir todos os homens sem distinção de nacionalidade, confissão ou de raça $\left({ }^{37}\right)$. Houve nítida consciência da diferença que separava a "fraternidade ideal» da «fraternidade real», a prédica moral da realização prática da propriedade comum, da produção comunitária e sua repartição, como em 1866 se exprimia J. Ph. Becker ${ }^{38}$ ). E que o ideal de fraternidade atravessou, irrealizado, o séc. XVIII e o séc. XIX, andou na boca de democratas e de socialistas, de conservadores e de liberais e inspira, no séc. XX, movimentos de unidade, de natureza social e política ou religiosa, como o movimento ecuménico. A gravidade dos grandes problemas, que são hoje internacionais e planetários, reclama uma nova figura da consciência humana, que repense e realize a solidariedade e a fraternidade na construção positiva e universal da paz.

Além dos conceitos convergentes de solidariedade e de fraternidade, o conceito de trabalho é outra coordenada mestra que se cruza na arquitectónica mental de Sérgio. A transformação do conceito de ciência anunciada, logo no séc. XVII, no aforismo de F. Bacon «scientia et potentia in idem coincidunt» ${ }^{39}$ ) traduziu-se no abandono dos argumentos e das disputas da Escolástica e na valorização das técnicas (artes) e do trabalho (opus), capazes de modificar a natureza $\left({ }^{40}\right)$. Este processo de emancipação intensificou-se com Th. Hobbes em virtude da subordinação de toda a teoria à acção (actio) e ao trabalho (operatio) e da substituição do "summum bonum» da contemplação pelo progresso e felicidade terrenos, já que o poder é a categoria fundamental do homem e o trabalho o conceito básico da sociedade $\left({ }^{41}\right)$. Foi J. Locke, porém, que descobriu no trabalho a força valorizadora das coisas e a justificação jurídica da propriedade $\left({ }^{42}\right) \mathrm{e}$, mediante esta promoção, o trabalho já não poderia realmente continuar associado a pobreza, a esforço e a fardo mas a riqueza, a alívio e até a prazer $\left({ }^{43}\right)$. Simultaneamente, apaga-se a oposição

$\left(\begin{array}{c}3 \mathrm{~T} \\ )\end{array}\right)$ W. Schieder, ob. cit., 578.

( $\left.{ }^{38}\right)$ Idem, ob. cit., 578-579.

("0) F. Bacon, "Novum Organon» in: Idem, The Works of Francis Bacon, Faksimille-Neudruck der Ausgabe von Spedding, Ellis und Health, London 1857-1874 in vierzehen Baenden, I Bb. (Stuttgart-Bad Cannstatt 1963) 157.

$\left.{ }^{40}\right)$ Idem, ob. cit., l.c., 154, 157, 158.

(41) Th. Hobbes, Levianthan or The Matter, Form and Power of a Commonwealth, Ecclesiastical and Civil (London s.d.) 61.

$\left(^{42}\right)$ J. Locke, Two Treatises of Government, a critical Edition with an Introduction and Apparatus criticus by $P$. Laslett ${ }^{2}$ (Cambridge 1967) 305-306, 314, 315.

$\left.\mathbf{i}^{43}\right)$ G. W. Leibniz, Sociataet und Wirtschaft, cit. por W. Conze, ob. cit., 169. 
entre artes e negócios, pois ambos são trabalho, o binómio trabalho-ócio é substituído por trabalho-jogo, ambos ocupações, e o trabalho já não imita a natureza mas transcende a ordem natural e é mediação entre o homem e a natureza, como modo tipicamente humano de ser-no-mundo. No final do séc. XVIII, estava já consolidada a tendência para emancipar o trabalho de qualquer fixação classista e para o referir ao homem em geral e o conceber como actividade, que abre caminho à felicidade individual e colectiva $\left({ }^{44}\right)$. Pelo trabalho o homem constitui-se homem e, por isso, à actividade laboriosa pertence a virtude da diligência ou da aplicação, elevada pela Aufklaerung a virtude cardial $\left({ }^{45}\right)$. Esta elevação moral do trabalho como actividade realizadora do homem justificou o interesse dos pedagogos da segunda metade do séc. XVIII pela sua estreita associação a «cultura» e «educação», pois o educando não só devia aprender a trabalhar mas também a exercitar na escola as suas aptidões para o trabalho $\left({ }^{46}\right)$.

Além da dimensão antropológica, ética e pedagógica do trabalho, o seu aspecto estritamente económico tomou-se com A. Smith matéria nuclear de uma disciplina especializada - a Economia Política. Pelo trabalho livre e nivelador dos homens multiplicam-se as possibilidades económicas de vida, satisfazem-se crescentes necessidades e a felicidade já não é esperada da sua união com a prece ou do isolamento da pura contemplação mas é simples produto da força própria, dos 'poderes produtivos' e da indústria, criadores de valores materiais, de condições de vida e da riqueza das nações. Este conceito de trabalho, gerador do valor económico, sempre que para dominar se isolou na sua autonomia, tendeu para o grau-zero da consciência moral.

Na Revolução Francesa, agudizada a distinção entre classes produtivas e improdutivas, apareceu a identificação da nação com o terceiro estado ou sociedade fundada no trabalho. Nas diversas formulações dos direitos do homem que se seguiram, o tema do trabalho apareceu ora implicado no da liberdade ora explicitamente referido como base relevante do direito de propriedade e assegurado na sua livre realização sem sombra de servidão $\left({ }^{47}\right)$, mas ainda não definido expres-

r) W. Conze, «Arbeit» in: O. Brunner-W. Conze-R.Kosellek, Geschichtliche Grundbegriffe 171.

kfurt/M. 1975) 55-59.

$\left({ }^{45}\right)$ O. F. Bollnow, Wesen und Wandel der Tugenden (Fran-

$\left({ }^{46}\right)$ W. Conze, ob. cit., 172-173.

$\left({ }^{4 T}\right)$ Idem, ob. cit., 182-183. 


\section{António Sérgio}

samente como «direito ao trabalho», fórmula que só aparece em 1808 em Ch. Fourier $\left(^{48}\right)$.

Emancipado mas simultaneamente disputado pelo espírito revolucionário e pelo economismo, o trabalho foi, nestas circunstâncias, tema da reflexão da filosofia idealista. Apesar de Kant negar ao trabalho o título justificativo de propriedade, que atribuía à ocupação $\left({ }^{49}\right)$, e de não o referir explicitamente na sua doutrina ética, no entanto da sua filosofia moral deduziu-se a libertação do homem e a dignificação de toda a sua actividade. Fichte, sensível à raiz antropológica do trabalho, considerou-o a concreção da actividade absoluta da liberdade do homem na natureza $\left.{ }^{50}\right)$, de que resultam a civilização e o progresso, visíveis no domínio material e económico, onde se inicia a realização da liberdade ou da exigência absoluta de um mundo melhor $\left({ }^{51}\right)$. Humano por essência, o trabalho não pode continuar um fardo ou uma pena na sua facticidade bruta nem o seu fim limitar-se ao crescimento económico, pois o que lhe dá sentido, é ser a libertação do esforço penoso ou do mal necessário suportado pelo homem para realizar o estado de "ócio livre», que é a «propriedade absoluta de todos» $\left({ }^{52}\right)$. Crítico do Economismo, Fichte viu no trabalho a força impulsionadora da civilização, a raiz da propriedade e, sobretudo, do aperfeiçoamento universal do homem e um título de nobilitação. Por isso, o âmbito do conceito fichteano de trabalho abrangia não só a actividade das classes chamadas economicamente produtivas mas também a da «classe dos sábios», altamente valorizada por Fichte $\left({ }^{53}\right)$. O pressuposto moderno de que a propriedade é essencial ao homem e só pelo trabalho se pode justificar, implicava logicamente a elevação do trabalho a um direito essencial e universal do homem, pois é condição indispensável ao seu poder-viver. Seguindo a ordenação hierárquica de

$\left({ }^{48}\right)$ A. Baruzzi, ob. cit., 38-42.

( ${ }^{40}$ ) I. Kant, «Grundlegung zur Metaphysik der Sitten» in: Idem, Schriften zur Ethik und Religiosphilosophie, hrsg., v. $W$. Weischedel (Wiesbaden 1959) 378.

(') J. G. Fichte, Das System der Sittenlehre (1798), Einleitung, ob. cit., 184.

$\left({ }^{51}\right)$ Idem, Die Bestimmung des Menchen (1800), ob. cit., 184.

$\left.C^{2}\right)$ Idem, Das System der Rechtslehre (1812), ob. cit., 185.

(") Idem, I, 8, Reden an die deutsche Nation (1808), apud W. Conze, ob. cit., 185. Idem, «Einige Vorlesungen ueber die Bestimmung des Gelehrten" in: Idem, Werke 1794-1796, hrsg., V.R. Lauth-H. Jacob (Stuttgart-Bad Connstatt 1966) 25-68. 
vida, direito e propriedade, Fichte tocou a raiz do Estado social de direito na formulação de dois axiomas: «E princípio fundamental de toda a constituição racional do Estado: cada um deve poder viver do seu trabalho»; «o poder viver é, por isso, condicionado pelo trabalho e não existe este direito, onde as condições se não realizarem» $\left({ }^{54}\right)$. Portanto, «deve também o Estado criar instituições», isto é, deve responsabilizar-se pela organização do trabalho. Para esta concepção do trabalho como direito essencial do homem, constribuiu, ao lado de Fichte, $\mathrm{Ch}$. Fourier, segundo o qual o direito ao trabalho substitui os direitos naturais do homem selvagem, que lhe foram extorquidos pela civilização $\left({ }^{55}\right)$.

Hegel, por seu lado, tomou consciência do ritmo crescente da divisão e da especialização do trabalho e do seu inevitável carácter progressivamente mais abstracto $\left({ }^{56}\right)$. Ao contrário do animal, o homem usa, não por instinto, mas racionalmente a natureza para satisfazer as suas necessidades e neste uso racional prático da natureza consiste a mediação do trabalho, cujo desenvolvimento histórico criou a figura do instrumento e da máquina. $\mathrm{O}$ trabalho, porém, não se confina ao espaço estreito das qualidades individuais mas exige a aprendizagem de regras gerais, portadoras da universalidade, objectiva e intersubjectiva, que distingue a racionalidade do trabalho. Assim, o instrumento é um meio racional permanente, construído segundo regras gerais, entre o homem e a natureza, destruindo entre eles o carácter da relação imediata. A mediação perfeita é realizada não por qualquer utensílio mas por um instrumento autónomo, isto é, pela máquina, a que o homem trespassa a sua função de trabalhar, «enganando a natureza» mas sofrendo a ameaça e o risco de um trabalho «morto», da diminuição das capacidades naturais e do embotamento da consciência $\left({ }^{57}\right)$. A abstracção concretizada na máquina arranca o trabalho à satisfação imediata das necessidades individuais e insere-o no serviço impessoal de uma satisfação universal possível de necessidades de outrem. Consagradas na sua prioridade intangível a universalidade e

( $\left.{ }^{M}\right)$ Idem, Grundlage des Naturrechts nach Prinzipien der Wissenschfslehre in: Idem, Werke 1797-1798, I, 4, hrsg., V.R. Lauth-H. Gliwitzky (Stuttgart-Bad Connstatt 1970) 22, 23. ob. eit., 42 .

(") Ch. Fourier, Traité de VAssociation, I (Paris 1922) 122,

( $\left.{ }^{\mathrm{M}}\right)$ Cf. K. Loewith, Von Hegel zu Nietzsche. Der revolutionaere Bruch im Denken des 19. Jahrhunderts. Marx und Kierkegaard (Stuttgart 1964) 286.

$\left({ }^{6 \mathrm{~T}}\right)$ Cf. G. W. F. Hegel, Jenenser Realphilosophie, hrs..$_{f}$ von J. Hoffmeister (Leipzig 1932) I, 177 ss., 220 ss,; II, 197 ss., 213 ss. 
a abstracção do trabalho, só colaborando na totalidade da satisfação das necessidades de outrem, com suspensão da intenção imediata das próprias, é que o trabalhador vale às próprias necessidades individuais, isto é, o valor do trabalho só através do sistema de dependências dos diversos trabalhos entre si atinge a pessoa concreta do trabalhador. Quanto mais universal e abstracto for o sistema de trabalho, maior será o grau de divisão e de especialização do mesmo trabalho e mais completa a dependência do trabalhador relativamente à natureza, que o espírito do trabalho moderno pretende dominar $\left({ }^{58}\right)$. Ao trabalho abstracto e ao «eu abstracto» ou «à maneira de coisa»» do trabalhador contrapõe Hegel o espírito enquanto «envolvente, pleno de conteúdo, circunspecto», dominador de «um grande horizonte» $\left.{ }^{59}\right)$. O mundo resultante deste trabalho sem espírito é «um sistema monstruoso de comunidade e de dependência mútua, uma vida de morto, que em si mesma se move, que.... necessita, como um animal selvagem, de constante domínio severo e de domesticação» $\left({ }^{60}\right)$. Este domínio, porém, só pode provir da força moral ou da liberdade entendida como suprema determinação do homem, pois o trabalho, como factor económico, jamais é fim em si mesmo mas deve mediar entre as necessidades humanas e a sua satisfação e entre esta e a liberdade. Ao contrário de Fichte, Hegel teve plena consciência da ambivalência do trabalho, que, se não está necessariamente vinculado à escravidão, também se não associa, por natureza, à liberdade, pois o progresso económico de uma sociedade pode coexistir com a diminuição ou perda da liberdade. Chamado a transcender a esfera meramente económica, o trabalho entretece relações histórico-metafísicas com o devir do espírito ou com a realização da liberdade, de acordo com a interpretação hegeliana do sentido bíblico da queda original, que não sentenciou o homem ao trabalho duro de uma terra ingrata mas impôs que, pelo trabalho, o espírito fosse livre e fosse por si mesmo o que é $\left({ }^{61}\right)$. O trabalho do homem deve corresponder ao trabalho do Espírito do mundo ou vontade de Deus, que é o "círculo superior do Bem», e elevar a esfera do natural e necessário à liberdade de uma segunda natureza espiritualizada,

${ }^{\mathbf{5 8}}$ Idem, ob. cit., I, 237-238.

$\left.C^{9}\right)$ Idem, ob. cit., II, 214-215.

(60) Idem, ob. cit., I, 240.

(C) Idem, Enzyklopaedie der philosophischen Wissenschaften im Grundrisse, Erster Teil, Die Wissenschaft (1830), Mit den muendlichen Zusaetzen, hrsg., v. E. Moldenhauer-K. M. Michel (Frankfurt/ M. 1970) 90. 


\section{Neo-iluminismo Filosófico}

superior ao mundo físico $\left({ }^{62}\right)$. Liberto o trabalho da estreiteza economista, o homem é activamente no mundo, age nele de modo prático com segurança de si mesmo, tomando-o livre como ele mesmo é. Nesta libertação, cercada de perigos, viu Hegel o sentido mais profundo do séc. XIX $\left({ }^{63}\right)$.

O trabalho como fundamento de uma sociedade igualitária foi tese comum ao socialismo primitivo, aos hegelianos de esquerda e a K. Marx. A existência humana funda-se apenas no trabalho, que é a dívida de todo o cidadão capaz para com a sociedade, com a exclusão total de toda a ociosidade, que deve ser banida como o roubo. $\mathrm{O}$ célebre princípio «à chacun selon sa capacité, à chaque capacité selon ses oeuvres» torna-se divisa de uma nova sociedade, em que o homem não explore mais o homem mas, associado, explore o mundo entregue ao seu poder $\left({ }^{64}\right)$, mudando a força guerreira do passado, inimiga do trabalho, num caudal pacífico de energia, transformador da natureza. Ao princípio liberal «Laissez faire, laissez passer» é contraposto pelos sequazes de Saint-Simon o conceito de «organização do trabalho», divulgado e actualizado politicamente por Louis Blanc $\left({ }^{65}\right)$ e considerado peça mestra da estrutura social.

$\mathrm{O}$ pensamento dos discípulos radicais de Hegel incidiu sobre o problema fundamental das relações entre filosofia e história do mundo e, neste contexto do ser histórico do homem a realizar-se, devem interpretar-se expressões como «realidade», «realização», «praxis», «existência», «político» e «social» $\left({ }^{66}\right)$. A filosofía da acção dos hegelianos de esquerda aprofundou o conceito de trabalho, defendendo com A. Ruge a unidade de trabalho e de liberdade na história do espírito e deduzindo as consequências sociais do conceito de trabalho súper-nacional, que define a essência do homem, é seu título honorífico e marca o nível da civilização. Em virtude da intrínseca união entre liberdade e trabalho, o estado da sociedade burguesa deve ser um estado de liberdade, em que a única estrutura é a do trabalho ou forma suprema de humanidade, organizada numa sociedade livre de trabalhadores manuais e intelectuais, com exclusão dos privilégios de quem

${ }^{\left({ }^{62}\right)}$ Idem, Grundlinien der Philosophie der Rechts 232, 434.

$\left.\mathbf{i}^{63}\right)$ Idem, Phaenomenologie des Geistes, hrsg., v. E. Moldenhaur-K. M. Michel (Frankfurt/M. 1970) 508-512.

$\left.C^{4}\right)$ Cf. C. Bouglé-E. Halévy, Ed., Doctrine de Saint-Simon, Exposition (1829) (Paris 1924).

${ }^{(65)}$ W. Conze, ob. cit., 198.

O K. Loewith, Die hegelsche Linke (Stuttgart-Bad Cannstatt 1962) 7-38. 
não trabalha e de todo o conceito económico de trabalho, que prescinda do homem. E que o fim primordial do trabalho não é a produção de um valor económico mas a realização do homem por si mesmo $\left({ }^{67}\right)$.

L. Feuerbach, ao transformar a teologia em antropologia, pretendeu purificar o trabalho de toda a fundamentação religiosa e restituir ao homem a sua plena autonomia de ser activo $\left({ }^{68}\right)$, no que foi seguido por F. Engels, defensor, contra o «evangelho do trabalho» de Th. Carlyle, do conceito humano mas radicalmente ateu de trabalho, a partir do postulado de que «Deus é o homem» $\left({ }^{69}\right)$. Este novo conceito de autonomia do trabalho humano, conseguido através da eliminação de toda a heteronomia religiosa, é ponto de partida do pensamento ergológico de K. Marx. Da Fenomenologia Espírito de Hegel é exaltada por Marx a ideia de que o homem pelo trabalho se cria a si mesmo no seu ser histórico concreto, mas, ao mesmo tempo, é depurado o pensamento de Hegel da componente espiritual e interpretado no sentido do materialismo de Feuerbach $\left({ }^{70}\right)$. Reduzida a história humana às transformações epocais do trabalho, a perda de autonomia coincide historicamente com «o pecado original económico» da primeira produção de bens excedentes, que deixaram de servir imediatas necessidades do homem, prefigurando a futura separação do capital e do trabalho. Esta perda de autonomia é a ruptura entre a existência e a essência do homem $\left({ }^{71}\right)$ e nela radica a compra e venda da força de trabalho. A essência, como «mais-valia», excede as condições mínimas de existência, é de facto realizada pelo trabalho desapropriado do homem e fora deste e só através de uma mutação radical deste estado de coisas é possível recuperar, com a unidade da existência e da essência, a autonomia do homem como trabalho. Na continuação da crítica hegeliana ao estilo

(") A. Ruge, Aus frueherer Zeit, Bd. IV (Berlin, 1867) 105 ss., 360 ss., 377. Cf. K. Loewith, Von Hegel zu Nietzsche 292 ss.: Idem, Die hegelsche Linke 7-38; W. Conze, ob. cit., 198-199.

(*) M. Xhaufflaire, Feuerbach et la Théologie de la Sécularisation (Paris, 1970) 149-265; Cf. H. Luebbe-H.-M. Sass, Atheismus in der Diskussion, Kontroversen zum Ludwig Feuerbach (Muenchen 1975) passim.

(") F. Engels, «Die Lage Englands Rez. Thomas Carlyle, Past and Present, Dt.-Franz. Jbb. (1844)» in: K. Marx-F. Engels, Werke, Bd.I (Berlin 1972) 546.

(TM) K. Marx, «Oekonomisch-philosophische Manuskripte 1844)» in: K. Marx-F. Engels, Ergaenzungsband, I (Berlin 1973) 574-588.

(") Idem, ob. cit., 520 . 
mecânico de trabalho e à sua abstracção, Marx não só reconheceu que o trabalho era realizado pelo «sistema automár tico da maquinaria» ${ }^{72}$ ), a què o trabalhador servia como escravo, num tédio de esforço monótono, mas também denunciou o carácter abstracto do trabalho «por todos os lados determinado e regulado pelo movimento da maquinaria» e não, inversamente, pelo trabalhador, pois o processo de produção não é regido pelo trabalho "como a sua unidade dominadora» $\left({ }^{73}\right)$. O trabalho da máquina domina o trabalho vivo reduzido a um apêndice de que enquanto capital se apropria, visto ser a sua essência apenas "um meio de produção de mais-valia» $\left({ }^{74}\right)$. Ao contrário de Hegel, Marx considerou possível a emancipação do homem trabalhador somente através de uma revolução, que, pela socialização dos meios de produção, convertesse o "sistema automático da maquinaria» em vida de trabalho realizadora da essência do homem numa sociedade, em que «o livre desenvolvimento de cada um seja a condição do livre desenvolvimento de todos» $\left({ }^{75}\right)$. Sendo o homem, por essência, trabalho ou produção material das condições de existência, Marx recusa, além do ócio como libertação, a ideia de trabalho no sentido de pena ou maldição, para nela considerar apenas a auto-realização, a objectivação do sujeito, a concretização da liberdade real $\left({ }^{70}\right)$ no «verdadeiro reino da liberdade», distinto do reino da necessidade natural $\left({ }^{77}\right)$.

É no reino da liberdade que a solidariedade, a fraternidade e o trabalho têm o seu lugar natural. A expressão «reino da liberdade», possivelmente preparada pelo texto paulino da carta Ad Gal. 5,1, pela «civitas libera» de S. Agostinho $\left({ }^{78}\right)$ e pela «perfectissima liberta» de S. Tomás $\left({ }^{79}\right)$, apareceu em

$\left.{ }^{72}\right)$ Idem, Das Kapital, Bd. I (1867) in: K. Marx-F. Engels, Werke, Bd. XXIII (Berlin 1972) 402.

$\left.\mathbf{C}^{73}\right)$ Idem, Grundrisse der Kritik der politischen Oekonomie (Rohentwurf) (Berlin 1953) 584 ss.

$\left({ }^{74}\right)$ Idem, Das Kapital, Bd. I in: K. Marx-F. Engels, Werke, Bd. XXIII, 391.

${ }^{75}$ ) K. Marx-F. Engels, Manifest der kommunistischen Partei (1848) in: K. Marx-F. Engels, Werke, Bd. IV (Berlin 1974) 482.

(76) K. Marx, Grundrisse... 504 ss.

$\left.\left({ }^{71}\right)\right)$ Idem, Das Kapital, Bd. Ill in: K. Marx-F. Engels, Werke, Bd. $X X V$ (Berlin 1973) 828.

$\left({ }^{78}\right)$ S. Agostinho, De Civitate Dei, XVIII, 20.

(Roma 1954) 226.

${ }^{(70)}$ S. Tomás de Aquino, Opuscula Theologica, ed. Spiazzi 
M. Lutero identificado com o Novo Testamento $\left({ }^{80}\right)$, em Goethe em oposição ao reino da natureza $\left({ }^{81}\right)$ e em Nietzsche ao lado da expressão sinónima «natureza livre» $\left({ }^{82}\right)$. A Kant se deveu um aprofundamento do sentido desta expressão, que também usou $\left({ }^{83}\right)$, na sua conhecida doutrina dos postulados, ao enraizar a acção moral na crença do nosso chamamento à realização da liberdade, como seres inteligíveis, membros de um mundo moral e inteligível, para lá do reino da natureza e a que chamou também «reino da liberdade». Antes, porém, da Revolução Francesa, referira-se já Schiller ao «reino da mais perfeita liberdade», no sentido do reino da verdade da ciência e da arte ${ }^{84}$ ). Em sentido político e social, esta expressão traduziu em 1813 o pensamento central da filosofia do Estado de Fichte, que, além de assentar na eliminação de todo o domínio do homem sobre o homem, exigiu a morte do poder do Estado identificado com a coacção $\left({ }^{85}\right)$. Ao contrário de Fichte, Hegel concebeu o Estado como a instituição fundamental surgida num longo processo histórico para possibilitar a liberdade humana no aspecto moral, jurídico e político, atribuindo-lhe um poder, que excluía toda a semelhança com o domínio de escravos $\left({ }^{86}\right)$. Distintas das leis da natureza, as leis do Estado devem ser reconhecidas pelos cidadãos de modo a constituírem o «universo moral» $\left({ }^{87}\right)$ como reino da liberdade entre nós. Superando o formalismo kantiano, Hegel situou a liberdade na vontade perante as coisas, inferiores à sua dignidade e perante outras liberdades, que lhe são cogeniais e mediam, enquanto outras, o regresso a si do sujeito. Transcendendo o universo coisista, «a liberdade quere a liberdade» $\left.{ }^{88}\right)$ não só no domínio particular

${ }^{80}$ L. Oeinz-Hanhoff, «Das Reich der Freiheit als absoluter Endzweck der Welt» in: J. Simon, Hrsg., Freiheit, theoretische und praktische Aspekte des Problems 63-64.

${ }^{(1)}$ J. W. Goethe, "Maximen und Reflexionen» in: Goethes Werke, Hamburger Ausgabe 5 (Hamburg 1963) 528.

${ }^{82}$ ) F. Nietzsche, «Richard Wagner in Bayreuth» in: Idem, Werke, kritische Gesamtausgabe, hrsg., v. G. Colli-M. Montinari, IV 1 (Berlin 1967) 41.

${ }^{(33}$ ) I. Kant, «Die Religion innerhalb der Grenzen der blossen Vernunft» in: Idem, Schriften zur Ethik und Religionsphilosophie, hrsg v. W. Weischedel (Wiesbaden 1956) 738.

${ }^{\mathrm{M}}{ }^{\mathrm{s}} \mathrm{L}$ L. Oeing-Hanhoff, ob. cit., 62.

( $\left.{ }^{85}\right)$ J. G. Fichte, Die Staatslehre oder ueber das Verhaeltnis des Urstands zum Vernunftreich, hrsg. v. I. H. Fichte, Bd. IV (Berlin 1845/1846) 418 s., 429, 433, 531, 580, 581, 591 s. 599. 122-126

i $^{86}$ ) G. M. F. Hegel, Grundlinier der Philosophie des Rechts

$\left.{ }^{87}\right)$ Idem, ob. cit., 15-16.

(88) Idem, ob. cit., 74. 
do encontro a dois mas nas esferas mais amplas e de crescente universalidade até à cúpula do Estado $\left.{ }^{89}\right)$. Entre as formas de liberdade, Hegel considerou de nível inferior a relação dos homens em virtude da posse das coisas, característica do mundo de proprietários ou de liberdades coisisticamente fixadas, sobre que versa o «direito abstracto». O mundo da liberdade começa propriamente no reino da moralidade em que a liberdade quer a liberdade, isto é, na família, na sociedade, na corporação e no Estado $\left({ }^{90}\right)$.

Também no pensamento marxista o reino da liberdade é a meta de todas as transformações radicais da sociedade. Assim, para K. Marx a verdadeira história natural do homem converteu-se no processo da sua emancipação $\left({ }^{91}\right)$ e, por isso, o reino da necessidade distinguiu-se do «reino da liberdade» $\left({ }^{92}\right)$ ou, na expressão de Engels, repetida mais tarde por Lénine $\left({ }^{93}\right)$, só por um «salto» é que se poderia constituir o «reino da liberdade» $\left.{ }^{94}\right)$. Segundo E. Bloch, o conteúdo substancial da consciência revolucionária, sob o ponto de vista marxista, deve ser «a profundidade do reino da liberdade» $\left({ }^{95}\right)$.

$\mathrm{Na}$ defesa da dimensão religiosa do reino da liberdade, que é exigida pela consciência moral como esta pelo empenhamento político, distinguiu-se a obra de J. Moltmann ${ }^{9 \mathrm{G}}$ ), a Teologia Política de J. B. Metz, amigo e interlocutor de E. Bloch, e a Teologia da Libertação ${ }^{97}$ ).

$\left.{ }^{800}\right)$ Idem, ob. cit., 46-83. Cf. K. Hartmann, «Die Objektivitaet der Freiheit, Hegelsphilosophie heute» in: J. Simon, Hrsg., Freiheit, theoretische und praktische Aspekte 318-320.

322.

(*o) Idem, oh. cit., 92-172, 292-512; Cf. K. Hartmann, ob. cit.,

( $\left.{ }^{91}\right)$ K. Marx, Zur Kritik der hegelschen Rechtsphilosophie in: K. Marx-F. Engels, Werke, $B d$. I (Berlin 1972) 504.

$\left.C^{2}\right)$ Idem, Das Kapital, Bd. III, $\mathbf{8 2 8 .}$.

$\left({ }^{\circ}\right)$ W. I. Lenin, «Die naechsten Aufgaben der sowetmacht» in: Idem, Werke, Bd. 27, Februar-Juli 1918 (Berlin 1972) 264-265.

$\left.{ }^{(\mathrm{M}}\right)$ F. Engels, "Anti-Duering» in: K. Marx-F. Engels, Werke, Bd. 20 (Berlin 1973) 264.

(95) E. Bloch, Atheismus im Christentum, Zur Religion des Exodus und des Reichs (Hamburg 1970) 256.

$O$ J. Moltmann, Theologie der Hoffnung 9 (Muenchen 1973) 197-204; Idem, «Die Revolution der Freiheit» in: Idem, Perpektiven der Theologie (Muenchen-Mainz 1968) 189 ss.

${ }^{\left({ }^{T}\right)}$ J. B. Metz, Zur Theologie der Welt (Mainz-Muenchen 1968); Idem, «Das Problem einer 'politischen Theologie' und die Bestimmung der Kirche als Institution gesellschaftskritischer Freiheit» in: Concilium 4 (1968) 403-411; K. Rahner-Ch. Modehn-H. Zwiefelhofer, Hrsg., Befreiende Theologie, der Beitrag Lateinamerikas zur Theologie der Gegenwart (Stuttgart-Berlin-Koeln-Mainz (1977), passim. 
É inegável que o problema da libertação alcançou no séc. XX dimensão ecuménica, embora as soluções dif̧erentes e, por vezes, opostas dividam os espíritos. O tema da liberdade é actual no mundo inteiro, mas em contextos sociais e políticos diversos, desde os movimentos de descolonização e emancipação da África, a libertação dos pobres e oprimidos na América do Sul, a concepção socialista de liberdade como revolução permanente contra a estagnação e a burocratização ou de liberdade como sistema e objectivação organizada do seu uso até ao Estado social das nações industrializadas, de tipo ocidental, em que a progressiva concentração das tarefas sociais no Estado é sentida como uma diminuição da liberdade ${ }^{98}$. Desta experiência contemporânea colige-se, com suficiente clareza, que uma diferença originária divide a liberdade dos sistemas que a pretendem realizar e é a partir desta diferença que se pode legitimar a crítica a estruturas estabelecidas. Também se torna evidente que não é a partir de coisas ou da natureza e suas leis que a liberdade se experienda mas nos outros e com outros, que foi através da emancipação da teocracia religiosa ou legitima secularização e da luta contra o excesso do poder político e económico que o homem moderno se concebeu como liberdade e que é na experiência ética do outro como incondicionado e não na sua funcionalização que a liberdade se revela solidária e fraterna. Fica assim suficientemente delineado o horizonte pressuposto pela crítica sergiana ao poder, pelo seu anti-coisismo, pela sua radical dimensão ética e pela sua universal secularização.

II. Da leitura das obras completas de A. Sérgio ressalta, à primeira vista, a sua estreita vinculação aos ideais do Iluminismo, com especial realce para a concepção de homem, que já M. Mendelssohn declarara "medida e fim» de toda a Aufklaerung ("). A história das «liberdades incompletas» iniciada na ruptura das condições sócio-culturais de vida do «ancien régime» e que urge continuar no mundo actual através de respostas adequadas às presentes condições históricas, revela os limites das diversas realizações do Iluminismo e impõe a necessidade de uma crítica a toda a apropriação actual

\footnotetext{
$\left({ }^{98}\right)$ H. Krings, «Reale Freiheit, Praktische Freiheit, Trans-

(") M. Mendelssohn, «Ueber die Frage: Was heisst aufsaetze (Frieburg-Muenchen 1980) 41-45.

(") M. MENDELSSOHN, "Ueber die Frage: Was heisst aufklaeren» in: N. Hinske, Hrsg., Was ist Aufklaerung? Beitraege aus der Berlinischen Montsschrift (Darmstadt 1981) 447-448.
} 
do ideal iluminista da liberdade e da autonomia concretas $\left({ }^{10 \circ}\right)$. Nesta linha crítica de realização contemporânea do ideal iluminista de liberdade e de autonomia situa-se a contribuição específica da obra filosófica de A. Sérgio.

Quanto ao pretenso influxo do Empirismo Inglês sobre o seu pensamento, A. Sérgio declarou em 1938, «para evitar descaminhos a genealogistas mentais», que as suas «preferências de idealista crítico são o que há de mais oposto ao empirismo, tendência esta característica de todo característico pensar britânico» $\left({ }^{101}\right)$. As suas «dívidas intelectuais» ou «afinidades electivas» concentraram-se, pelo contrário, em pensadores de outra estirpe: Platão, Espinosa e Kant e não propriamente em Descartes, embora o tivessem considerado já essencialmente cartesiano, «o que era, se não propriamente inexacto, pois todos os modernos racionalistas são um pouco discípulos de Descartes - pelo menos muito pouco preciso»». É importante esclarecer o modo tipicamente sergiano de leitura dos filósofos reconhecidos por antepassados intelectuais seus, isto é, evidenciar os pressupostos imediatos da sua hermenêutica filosófica. Reassumindo no séc. XX o espírito do Iluminismo, A. Sérgio confessou ter sido o convite a uma actividade crítica dirigido ao leitor e não «a propaganda de um catecismo adoptado»» o objectivo primordial do resumo do «idealismo moderno» que escreveu $\left({ }^{102}\right)$, pois a filosofia não é «um corpo de dogmas que se adopta e que se defende» mas «uma actividade espiritual de dilucidação das ideias, um trabalho de reflexão sobre as operações do espírito, - na ciência, na arte, na moral, na religião». Este ideal de "pensar por si mesmo», com recusa da orientação e da condução tutorials de outrem, próprias da menoridade, exige, como escreveu Kant, coragem e decisão $\left({ }^{103}\right)$ e significou no séc. XVIII o alvorecer da razão humana universal, para além de qualquer sistematização, partido ou arbitrárias regras de jogo, à maneira de um ideal, que, através da discussão pública e apartidária, conduzia ao reconhecimento do momento de verdade

$\left.{ }^{10 \circ}\right)$ Cf. W. Oelmueller, Was ist heute Aufklaerung? (Düsseldorf 1972); Idem, Die unbefriedigte Aufklaerung. Beitraege zu einer Theorie der Moderne von Lessing, Rant und Hegel (Frankfurt/M. 1969); M. B. Pereira, «Iluminismo e Secularização», Separata da Revista de História das Ideias (Coimbra 1982) 442-443.

$\left.\mathbf{C}^{\mathbf{1 0 1}}\right)$ A. Sérgio, «Genealogia intelectual», Seara Nova, $\mathbf{5 8 0}$
$\mathbf{3 7 5}$. boa 1972$) 229$.

(103) I. Kant, «Beantwortung der Frage: Was ist Aufklaerung?» in: N. Hinske, $o b$. eit, $\mathbf{4 5 2}$. 
de cada posição e pretendia a realização progressiva da universalidade da razão e da verdade indivisa $\left({ }^{104}\right)$. Para Sérgio, «a filosofia é a ginástica da reflexão sobre a ciência e essencialmente antidogmática», não propagandeia qualquer "credo idealista», próprio ou alheio, que se impusesse "como Autoridade e Papa». Foi a partir de «uma reflexão pessoal sobre a geometria analítica e sobre a física matemática» que se desenvolveu a problemática filosófica sergiana e não «pela dócil leitura de qualquer autor filosófico, de qualquer representante do idealismo moderno» $\left({ }^{105}\right)$. À evidência do pensamento que pensa por si mesmo, é consubstanciai a crítica a toda a autoridade no bom estilo da Ilustração e, por isso, a clareza autónoma da razão não está na quantidade de saber objectivo mas no modo de saber ou de compreender o que se sabe, «isto é, de lhe aprofundar a natureza, de lhe apreender o significado, de o conceber claramente, de lhe medir o alcance» $\left({ }^{106}\right)$. O modelo deste modo esclarecido de saber apareceu a Sérgio no génio da geometria analítica e da física matemática, isto é, na passagem da esfera da sensibilidade para o campo das relações matemáticas e na tendência a definir o objecto científico pelo próprio resultado da operação matemática $\left({ }^{107}\right)$. Da impressão causada pela geometria analítico e pela física matemática surgiram os primeiros problemas filosóficos e à luz destas ciềncias, leu Sérgio Espinosa, Platão e Kant $\left({ }^{10 \$}\right)$. Ao papel da ciência na formação do seu pensamento aludiu Sérgio, ao responder a críticas que lhe haviam dirigido, lembrando que tirara um curso de ciências exactas, que mantivera estreitas relações de amizade com verdadeiros cientistas, como Paulo Langevin, Eduardo Claparède e sempre vivera em comunicação com cientistas («com os quais eu me entendo muito melhor que com líteras»), que havia pesquisadores deste país português que decidiram dedicar-se à investigação científica por efeito da leitura dos seus Ensaios, que sempre definira toda a filosofia como um trabalho de reflexão sobre a actividade, sobretudo científica do espírito e que na sua juventude de oficial da marinha costumara aplicar ao viver quotidiano conhecimentos precisos de ciências exactas $\left({ }^{109}\right)$. Foi devido ao trânsito da sensi-

\footnotetext{
${ }^{104}$ M. B. Pereira, ob. cit., 481-482. $99 Q 930$

(105) A. Sérgio, «Notas de Esclarecimento» in: Idem, Ensaios II

$\left.C^{06}\right)$ Idem, ob. cit., 230.

( ${ }^{\mathbf{m}}$ Idem, ob. cit., l.c.

$\left.C^{18}\right)$ Idem, Ensaios P (Lisboa 1976) 34.

(109) Idem, «Notas de Esclarecimento», 235-236.
} 
bilidade para a relacionação matemática praticado pelas ciências que Sérgio, antes de 1er qualquer filósofo, sentiu «um livor de platonismo» e iniciou a leitura de Espinosa ainda antes da de Platão $\left({ }^{110}\right)$. Mais do que quaisquer autores, é privilegiada e reiterada a influência da geometria analítica que estudara na Escola Politécnica, pois por meio dela «é que sobretudo Descartes me impressionou» $\mathrm{C}^{111}$ ) e por ela se sentia em tudo o que escreveu sobre filosofia, política, história, moral, etc., um fundo comum e uma concatenação orgânica total, resultante de intenções essenciais de harmonia, que Sérgio procurava dentro de si e que encontrou em Platão, em Espinosa e em Kant $\left({ }^{112}\right)$. A descoberta de uma razão que em si mesma tem a luz e o critério da inteligibilidade, permitiu a Sérgio encontrar-se nos livros que lera, «porque aquilo que cada um lê nos autores, depende daquilo que cada um è» ${ }^{(113}$ ). Neste sentido, os casos de influências «não resolvem em definitivo problema algum», pois, pela cogenialidade, o leitor já é aquilo que vale a pena discutir nos textos seleccionados. O que, porém, Sérgio, leitor de filósofos, era, não se reduzia a dogmas de qualquer fé ou a opiniões e ideias constituídas mas simplesmente à atitude crítica «de quem está convencido de que nenhuma opinião antiga ou actual se deve tomar como ponto de fé mas como algo sujeito à discussão e à crítica, e que todos têm o direito de discutir, uma vez que possuam uma dose mínima de inteligência e de conhecimento sólido daquele mesmo assunto que se está tratando» $\left({ }^{114}\right)$. Não foi o conteúdo mas o espírito crítico, a dúvida metódica, a objectividade indagadora, o desejo de coerência e a lucidez mental, que aproximaram, por laços de parentesco espiritual, A. Sérgio de Platão, Montaigne, Descartes e Francisco Sanches $\left({ }^{15}\right)$. A relacionação matemática de Platão, a concepção espinosiana da unidade do todo e da coerência intrínseca como critério de verdade e a hipótese kantiana de uma inteligência, dinâmica e criadora, com o poder de constituir o objecto do conhecimento, encontraram imediata correspondência na atitude crítica de Sérgio, estruturada segundo as coordenadas da relação, da totalidade como sistema e da actividade criadora da razão.

$\left.C^{10}\right)$ Idem, ob. cit., 230.

$\left({ }^{\mathrm{m}}\right)$ Idem, "Genealogia intelectual», 375.

(112) Idem, ob. cit., P.c.

$\left.C^{13}\right)$ Idem, ob. cit., 376.

${ }^{\mathrm{m}}{ }^{\mathrm{m}}$. Idem, ob. cit., l.c.

(') Idem, ob. cit., l.c. 
Do ponto de vista cronológico, após o estudo das ciências matemáticas, Sérgio leu Espinosa e só mais tarde conheceu Platão, interpretando a alegoria da caverna e alguns trechos da República, do Teeteto, do Menon e do Sofista «livre e fantasiosamente e não na atitude do erudito histórico» $\left({ }^{116}\right)$. Daqui resultou um platonismo próprio, profundamente kantiano, sem qualquer preocupaçã̃o pelo Platão histórico, em que as ideias ou formas não eram simples conceitos mas equações da Geometria Analítica e da Física Matemática. Deste modelo científico dependeu a interpretação da caverna de Platão e «todos os que demandarem as regiões filosóficas a partir das paragens do saber exacto» encontram, no fim do seu percurso, Platão, a exemplo de Copémico e de Kepler $\left({ }^{117}\right)$. Avesso a propagandear qualquer corpo de ideias, Sérgio propôs-se emancipar os leitores portugueses, treinando-lhes a inteligência através não de uma ortodoxia mas de uma ginástica mental, como um pedagogo e não como um prosélito.

Dois escritores portugueses seduziram Sérgio no período da adolescência: Herculano e Antero. A este fícou a dever a sua iniciação política e a ele se julgou fiel através da concretização das tendências nele detectadas. "O grande Antero», na Questão Coimbrã, continuou a obra de Alexandre Herculano, como este reatara a de Luís A. Verney e exprimiu a revolta da literatura jovem contra uma literatura de mera forma, sem profundidades e sem saber $\left({ }^{118}\right)$. A História de Portugal de A. Herculano e o Verdadeiro Método de Estudar de L. Verney são os «dois grandes golpes do espírito crítico na muralha que nos separa da Europa culta desde o fim da época das Navegações» $\left({ }^{119}\right)$.

O socialismo democrático cooperativista pareceu a Sérgio enquadrar-se perfeitamente na filosofia da consciência inspirada em Platão e em Kant, com relevo para a ideia de espontaneidade radical do intelecto e do seu poder criador na percepção e na ciência e para as célebres formas platónicas, interpretadas como relações imanentes ao devir e traduzidas pelas equações da Física e da Geometria Analítica $\left({ }^{12 \circ}\right)$. Para Sérgio, Platão, poeta-geómetra e racionalista $\left({ }^{\mathrm{m}}\right)$, é o cria-

(IIf) Idem, «Notas de Esclarecimento», 230.

(') Idem, ob. cit., 230-231.

(118) Idem, «O Reino Cadaveroso ou o Problema da Cultura em Portugal» in: Idem, Ensaios II (Lisboa 1972), 53.

(119) Idem, ob. cit., 52.

(120) Idem, "Prefácio da Segunda Edição» in: Ensaios $V$ (Lisboa Idem, Ensaios III (Lisboa 1972), 56. 
dor de uma filosofia de espiritualismo estreme, assente na idealidade pura das relações matemáticas e, pelas doutrinas dos diálogos, tornou-se «a fonte imperecível do idealismo europeu, do humanismo científico, das formas superiores do pensar filosófico, que se não querem divorciar do saber mais nítido que é aquele que se exprime pelas equações» $\left({ }^{122}\right)$.

O pensar por si mesmo do Iluminismo, convertido por Sérgio em atitude crítica, determina-se agora, nos seus contornos, pela oposição à Idade Média, que definiu a Modernidade. «Para Ribeiro Sanches», escreve Sérgio, «no séc. XVIII, Portugal é o 'Reino Cadaveroso' e um satírico inteligente chama-nos «o Reino da Estupidez». No séc. XX, porque não impera em Portugal a «cultura autêntica», «a cultura crítica», continuamos o «Reino Cadaveroso» e o "Reino da Estupidez» $\left({ }^{123}\right)$. Ora, o espírito crítico é caracterizado por Sérgio pela sua oposição à Idade Média nestes termos: ao «apego ao Dogma e à Autoridade», à limitação do espírito crítico e à ausência do método experimental, que distinguiram o medieval, opõe-se «o moderno intelecto» com o seu espírito crítico, a aplicação da Matemática e o método experimental, desabrochando em mentalidade audaciosa no séc. XVI para se firmar no séc. XVII, que era de luz para a Europa mas de treva para Portugal $\left({ }^{124}\right)$. O «labor intenso e pertinaz» da Escolástica foi um comentário sem fim de concepções definitivas e indubitáveis, onde era impossível penetrar a crítica. Pondo de lado o problema religioso («não falamos de religião, porque não é preciso»), Sérgio fixa-se no estudo das coisas físicas, das ciências naturais, que «foram tomadas pela Escolástica como constituídas definitivamente pelas especulações aristotélicas» $\left({ }^{125}\right)$. Comenta-se quando nada há para investigar ou discutir e daí os comentários à Física de Aristoteles, cujas especulações «foram tidas pela Idade Média como uma coisa tão dogmática, perfeita, indiscutível, como a Bíblia nas questões de fé»» $\left.{ }^{126}\right)$. Estes textos aristotélicos foram mumificados e purificados de toda a veleidade de progresso a fim de se conciliarem «completamente com as hipóteses transcendentes, ditadas pela teologia» $\left({ }^{127}\right)$. Resumindo a sua leitura da Idade Média, Sérgio afirma que «se tomava Aristóteles como divino, inquestionável, onde ele é nulo: no sis-

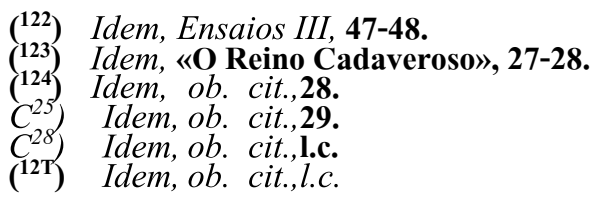




\section{Antonio Sérgio}

tema científico da sua obra, na sua Física qualitativa», com o afastamento da concepção mecânica da Física, «quantitativa e matemática, a única fecunda e de futuro», a única que permite a verificação rigorosa. Na sequência da crítica iluminista da autoridade, a ciência concebida segundo o modelo matemático é declarada incompatível com toda e qualquer autoridade, que tutela a menoridade do homem: «O grave da ocorrência.... não era que a autoridade fosse uma ou outra: era que houvesse uma autoridade qualquer» $\left({ }^{128}\right)$. Do mundo medieval dos dogmas, dos textos, dos comentários, das «subtilezas formais» e do «jogo verbal de ilusões aéreas», onde Sérgio não descortinou quaisquer linhas de evolução científica nem movimentos de emancipação, só se pôde libertar o homem mediante uma força vinda do exterior - «o desenvolvimento da indústria e do comércio», que aproximou as mais variadas gentes e já na Antiguidade compelira a cidade de Atenas às revoluções intelectuais dos Sofistas e de Socrates. Analogamente, «a faina industrial e o comércio marítimo impeliram à revolução o italiano; e foram as navegações e os descobrimentos (filhos das necessidades comerciais) que iniciaram na nova atitude a mentalidade do Português»» $\left.{ }^{129}\right)$.

E a partir da crítica tenaz à autoridade que Sérgio lê $e$ essência da Modernidade, cujos fundadores moveram uma luta violentíssima contra a tirania da Autoridade, que era neste caso a de Aristoteles, lutando a favor da criação sem peias da liberdade de investigação da Fisis, dos processos críticos e experimentais. $\mathrm{O}$ «espírito livre» de Kepler ou de Galileu forjou-se na luta contra «as gentes fanáticas da Autoridade» e o seu escolasticismo representou, na altura, «uma audácia descomunal» $\left({ }^{130}\right)$. Esta faceta negativa da emancipação e da crítica é positivamente compensada pelo método experimental e pela aplicação da Matemática à Física, sem a qual «não há ciência física que se tome a sério», pois «a Física.... ou é Física quantitativa (o contrário da de Aristoteles) ou não é nada» $\left.{ }^{131}\right)$. O abandono da Matemática é uma corrupção da doutrina platónica e, por isso, com Aristoteles, em vez da distinção fílosófica do sensível e do inteligível, surge «a distinção transviadora e mítica de duas ordens de cousas sensíveis: o sensível de baixo e o sensível de cima, o sensível humano e o sensível astral, o sensível da terra e o

\footnotetext{
$\left.{ }^{\mathbf{1 2 8}}\right)$ Idem, ob. cit.,l.c.

C'20) Idem, ob. cit.,30.

(130) Idem, ob. cit.,31.

(131) Idem, ob. cit.,32.
} 


\section{Neo-iluminismo Filosófico}

sensível do céu....» $\left({ }^{132}\right)$. A esta corrupção praticada por Aristoteles se ficou devendo que «por vinte séculos, (até o cogito aurorai de Descartes) nunca mais na terra desta nossa Europa se buscou a Deus por movimento centrípeto, - para dentro de nós, no foco luminoso do inteligível, pelo claro modelo das relações matemáticas, segundo o idealismo racional de Platão: buscou-se pelo processo da imaginação realista, no 'além' da esfera das constelações» ${ }^{133}$ ). A lógica de Aristoteles, interpretada por Sérgio como «a árvore genealógica de conceitos, a pirâmide de vocábulos de extensã̃o decrescente, a faculdade classificadora e discursiva», não é a lógica da investigação científica, porque a operação essencial do intelecto não é atribuir um predicado a um sujeito mas é relacionar, é religar a parte ao respectivo todo por meio da clareza de uma relação mental, a exemplo de Platão e de Descartes. Na lógica predicativa e discursiva de Aristoteles filia-se «a imensa maioria dos grandes erros, das perdas de tempo, dos mal-entendidos, das confusões» $\left({ }^{134}\right)$.

Sob o tríplice pressuposto da crítica à autoridade, do modelo matemático de ciência e do experimentalismo, Sérgio considera «afirmação cabalmente justa» a distinção feita por um autor inglês de «três clarões de verdadeira cultura» em toda a história do mundo europeu: o do escol ateniense do século quinto, o do escol italiano do Renascimento e o do escol francês do séc. XVIII $\left({ }^{135}\right)$, isto é, são especialmente valorizadas aquelas épocas da história ocidental que se distinguiram por movimentos de autonomia, libertação e emancipação da razão. $\mathrm{O}$ «papel libertador» desempenhado na Itália pela actividade mecânica industrial coube, entre nós, à navegação, que a países exóticos nos fez abordar, forçando-nos ao exame directo dos fenómenos da natureza, ao estudo da Matemática e à visão assídua de espectáculos novos e convencendo os portugueses dos «erros enormes das Autoridades, a cujas afirmações se prestava fé como a revelações do próprio Deus» $\left({ }^{136}\right)$. Nas suas grandes navegações, notaram os nossos avós «os enganos das Autoridades (profanas e eclesiásticas) e perderam, portanto, perante os textos a atitude de superstição». Com Duarte Pacheco Pereira e Garcia da Orta, atinge-se «o

\footnotetext{
(132) Idem, «Considerações sobre o problema da Cultura» in: Idem, Ensaios III (Lisboa 1972), 48.

${ }^{(133)}$ Idem, ob. cit., 49.

$\left({ }^{134}\right)$ Idem, «Migalhas de Filosofia» in: Idem, Ensaios VIII (Lisboa 1974), 194-195.

(136) Idem, «Considerações sobre o problema da Cultura», 40.

(136) Idem, «O Reino Cadaveroso», 33.
} 
momento da maior altura na vida mental do nosso país» e significado idêntico têm as obras de D. João de Castro, de Duarte Barbosa, de Pedro Nunes e de Camões $\left({ }^{137}\right)$.

Dos três magnos livros da Modernidade - Natureza, Bíblia e Antiguidade Clássica - Sérgio refere, além do mundo físico, a literatura, com especial relevo para Erasmo e, entre nós, para Damião de Góis e pergunta se seria o espírito do humanismo crítico o que animava os homens que D. João III chamou para reformar a Universidade $\left({ }^{138}\right)$. Omite, porém, qualquer reflexão sobre o aspecto científico da interpretação de textos e limita-se a afirmar que o intelecto português do Renascimento naufragou entre «os dois fanatismos, o da grei católica e o dos protestantes» $\left({ }^{139}\right)$, acabando-se «a viagem nos mares do Espírito». Mais funesto do que a História Trágico-Marítima, foi o naufrágio «da nau da Inteligência, que buscava a aurora, o da mentalidade crítica do Português» $\left({ }^{140}\right)$. Nesta linha interpretativa, o séc. XVII foi o campo «da batalha decisiva entre o homem do Espírito crítico e o homem da Idade Média; entre a ideia do livre exame e a ideia da autoridade; entre a inteligência concebida como íntimo dinamismo de relacionação e a inteligência concebida como árvore genealógica de palavras vácuas; entre as obras dos criadores e as obras dos comentadores» $\left({ }^{141}\right)$. Foi de recessão cultural o séc. XVII em Portugal, pois tudo era então "peripatético e medieval, além de barroco; e se foram feitas com inteligência as navegações de descobrimento, as navegações de comércio da índia foram pura obra de estupidez» $\left({ }^{142}\right)$. Quando no tempo de D. João $\mathrm{V}$ se iniciou a batalha da reentrada de Portugal na Europa, verificou-se que a primeira necessidade «era modernizar a mentalidade, substituindo a mediévica orientação das nossas classes preponderantes pelo espírito crítico e experimental» e destruindo «a peripatética em que se réduira o Português»», preso da ignorância do que o séc. XVII trouxera de novo relativamente à incompatibilidade entre o pensar aristotélico e o pensar científico e à criação das novas formas de conhecimento da relacionação matemática e da experimentação $\left({ }^{143}\right)$.

\footnotetext{
(m) Idem, ob. cit., 36-37.

(138) Idem, ob. cit., 39.

(139) Idem, ob. cit., i.c.

(140) Idem, ob. cit., 40.

$\mathrm{O}^{41}$ Idem, ob. cit., i.c.

(m) Idem, ob. cit., 41-42.

(143) Idem, ob. cit., 44, 48.
} 
Esta caracterização da razão crítica e experimental necessita de ser complementada por um conceito positivo de autoridade. Esta só se justifica pelo objective que se propõe, isto é, a autoridade não é um fim mas um meio ao serviço do homem e do seu maior bem, que é a liberdade e, nesse sentido, Sérgio interpreta o capítulo XXII, 24-29 do Evangelho de S. Lucas $\left({ }^{144}\right)$. Libertar por excelência é que é «verdadeira missão divina», pois Cristo veio ao mundo para "pôr em liberdade os oprimidos, pregar aos cativos remissão, evangelizar especialmente a gente pobre» e entre os objectivos da sua pregação jamais figurou a autoridade. Por isso, a função do homem de autoridade deve ser trabalhar por se tornar dispensável $\left({ }^{145}\right)$. Aplicando este conceito à sociedade, Sérgio situa o ideal de uma sociedade verdadeiramente humana na sua independência relativamente "a ministros, a politicoes, a chefes», como deve ser, aliás, uma república cooperativa, concluindo que «o melhor político, como o melhor pedagogo, é aquele que trabalha por se tornar dispensável» $\left({ }^{146}\right)$. Insistindo nesta mesma ideia e completando-a com o conceito de auto-emancipação, escreve mais adiante que só pode considerar «cabal político» aquele «que sentir certo enfado pelo poder que exerce, e que, por isso, se esforce por se tornar dispensável, ensinando o povo e emancipar-se a si mesmo pela autodisciplina no trabalho em comum, na cooperação fraterna» $\left({ }^{147}\right)$. São admissíveis as ditaduras temporárias mas com o escopo final de uma libertação maior e sob a condição de se tornarem em breve inteiramente dispensáveis, desenvolvendo no que respeita ao económico, as várias formas de cooperativismo, capazes de promover a justiça social e de tornar «quase dispensável.... a actuação do Estado» $\left({ }^{148}\right)$. Nesta ordem de ideias, Sérgio enumera as condiçções em que um ditador pode ser também um condutor: a) «buscar, antes de tudo e por meios directos, que se tornem menos pobres as classes pobres, as mais numerosas do seu País; b) «educar a massa da sua gente para fazer melhor uso da liberdade, em vez de se guiar pelo ideal absurdo de a manter etemamente tutelada»;

$\left.{ }^{144}\right)$ Idem, «Diálogos de Doutrina Democrática» in: Idem, Democracia, Diálogos de Doutrina Democrática, Alocução aos Socialistas, Cartas do Terceiro Homem ${ }^{2}$ (Lisboa 1974) 21; Idem, «Relanços de Doutrina Democrática» in: Idem, Ensaios VII (Lisboa 1974), 171. ${ }^{14 C}$ Idem, "Diálogos de Doutrina Democrática», 22. cia, 139.

(146) Idem, "Cartas do Terceiro Homem» in: Idem, Democra-

$\left.{ }^{\mathbf{1}}{ }^{147}\right)$ Idem, ob. cit., $\mathbf{2 5 6}$.

(148) Idem, ob. cit., 151. Cf. Idem, «Diálogos de Doutrina emocrática», 27, 63, 67. 
c) «trabalhar por ele próprio se tomar dispensável, capacitando o povo a governar-se a si próprio» $\left({ }^{149}\right)$. É que para Sérgio a política era uma arte de emancipar os homens e todo aquele que trabalhasse nesta emancipação era um condutor. Interessado na morte do Estado tentacular, o socialismo sergiano nasceu antiestatista e liberal ou libertário $\left({ }^{150}\right)$, pois «cooperativismo e estadualismo são dois conceitos que se repelem», «todo o cooperativismo é, por natureza, antiestatal» e nele «há exclusão absoluta da mais pequena intervenção do Estado nas fainas de direcção da vida económica» $\left({ }^{151}\right)$. Perante o fenómeno da revolução russa, Sérgio pretende "satisfazer melhor do que o bolchevismo, sem violências nem tira ${ }^{\wedge}$ nias, o ideal de justiça que se ele propôs», sem se apoderar do Estado e do seu domínio absoluto, mas desenvolvendo o Cooperativismo «dentro da sociedade capitalista, como se desenvolveu o Capitalismo dentro da sociedade senhorial» através do método essencialmente económico da criação de cooperativas $\left({ }^{152}\right)$, pois «o serem os homens patrões de si mesmos (tanto no económico como no moral e no político) é o que nós chamamos Democracia» $\left({ }^{153}\right)$. Por isso, gerado na antinomia entre liberdade e poder, o socialismo sergiano não é de Estado mas cooperativista, em que a socialização prudente dos grandes meios de produção e de troca não é efectuada pela autoridade nem realizada pelo poder do Estado mas pela iniciativa e liberdade dos trabalhadores unidos em cooperativas $\left({ }^{154}\right)$. A Democracia e o Socialismo puros são metas de um movimento que se há-de realizar por etapas, desenvolvendo-se no seio do capitalismo como este se gerou na matriz do regime feudal e apresentando, de início, o aspecto de um présocialismo ou pré-democracia social e política, caracterizada por uma «planificação para benefício de todos e não com o objectivo de conseguir um lucro, que é o objectivo do próprio Capitalismo»» $\left({ }^{955}\right)$. Esta realização por etapas exige acção e compromisso imediatos e rejeita todo o sonho utópico, que roube o sentido da realidade presente, pois nada há de mais

\footnotetext{
(149) Idem, ob. cit., 301. Cf. Idem, Antologia DemocráticaPátio das Comédias, Das Palestras e das Pregaçôes (Lisboa 1978), 5. ${ }^{1 \mathbf{1 G 0})}$ Idem, «Diálogos de Doutrina Democrática», 35; Idem, «Relancos de Doutrina Democrática», 171-172, 179-180. cia. 281.

$\left.{ }^{151}\right)$ Idem, «Cartas do Terceiro Homem» in: Idem, Democra-

(152> Idem, «Diálogos de Doutrina Democrática», 34

${ }^{153}$ Idem, ob. cit., 62.

$\mathbf{C}^{54}$ Idem, ob. cit., 30-31. 112-113.

$\left.{ }^{155}\right)$ Idem, «Alocução aos Socialistas» in: Idem, Democracia,
} 
contrário ao cooperativismo do que «a ideia de sacrificar os homens de hoje a uma felicidade problemática dos de amanhã, ou a ideia abstracta de 'Nação'»' $\left({ }^{156}\right)$. Atento aos sinais do tempo e às suas irreversíveis exigências concretas, Sérgio pressente no espírito da juventude o desejo de uma República de hoje, consonante com as aspirações desta época, concebida concreta e minuciosamente, por exame dos factos e explicada ao povo de modo claro, prático, racional, positivo, com largueza de vistas e tolerância lúcida $\left({ }^{157}\right)$.

Há, porém, em Sérgio um conceito eminentemente positivo de autoridade. A sua crítica, ao dirigir-se contra a autoridade externa de certos homens ou de um certo homem sobre outros, visou fundar a Democracia na autoridade interna de cada um de nós, isto é, no «império do racional de cada alma cívica sobre os seus próprios impulsos e paixões». Esta autoridade interna exige «a ideia moral do autodomínio», a «concentração da psique», a instalação da «ideia de governo e império» «dentro do espírito do cidadão», a submissão dos «impulsos e das ambições do mando ao ponto de vista racional, que é o ponto de vista do social», a identificação da Democracia a disciplina interna e a política do Espírito ( $\left.{ }^{158}\right)$. A autoridade interna é ditada pela Razão em cada um de nós, é «lei da consciência dessubjectivada» e, por isso, jamais se poderá aceitar uma «obediência do espírito», que signifique «a limitação do nosso juízo» iluminado pela luz racional ou a promoção da mentira contra os ditames da Razão $\left({ }^{159}\right)$.

III. A crítica a que Sérgio submete o conceito de autoridade, não se deve dissociar da sua concepção 'retro-coisista' da consciência e 'trans-coisista' de mundo. A recusa de que «seja coisa possível o ser-se mais experimentalista do que eu próprio sou», não implica «a necessidade de se ser materialista», pois a «experiência é logo de início gerada e estruturada por intervenção de ideias» $\left({ }^{16 \circ}\right)$ e tudo se pode dizer $a$ priori em certo sentido, em virtude do espontâneo actuar da nossa vida psíquica, oposto à estampagem do chamado mundo externo, que apenas estimula a psique mas não imprime nem reflecte nada, como já afirmara Kant. Daí, a energética da Razão, cujas ideias são factores, teorias ou interpretações da experiência. Os dados dos sentidos ou as intuições da experiência são inseparáveis das ideias, todos insertos na glo-

\footnotetext{
${ }^{\mathbf{1 5 6}}$ Idem, «Democracia» in: Idem, Democracia, 97.

$\left.{ }^{16 T}\right)$ Idem, "Cartas do Terceiro Homem», 263.

(158) Idem, «Paideia» in: Idem, Ensaios VII (Lisboa 1974), 283.

(1C) Idem, «Diálogos de Doutrina Democrática», 56.

(160) Idem, «Notas de Esclarecimento», 210.
} 
balidade da experiência, dada «a íntima ligação vivaz de quaisquer sentires com quaisquer ideias» $\left({ }^{16}\right)$. A experiência não é apenas um sinal sensível, nem uma ideia pura ou forma nem tão-pouco a sensação mas a «indestronável ligação do Sentir e da Ideia, sempre estruturada por interpretações do intelecto» $\left({ }^{162}\right)$, sempre actividade e interpretação int electi va. No acervo sensível, de extrema variabilidade, só é possível a ciência, se houver invariantes ou formas e, deste modo, se opõe o sensível inicial ou o sentir ao real ou à experiência, a intuição sensível à realidade, que implica sempre uma operação ideal do intelecto. Embora a ciência física se afaste da intuição sensível inicial, nem por isso se realiza «de costas para a realidade», pois jamais é lícito confundir a realidade física ou a Fisis com os seus indícios, que são as intuições sensíveis. Para Sérgio, «voltar as costas» à intuição sensível e resistir à obsessão da sensibilidade é volver a frente para a realidade física, como acontece na alegoria da caverna, pois só resistindo à atracção dominadora do sensível é que podemos inteligir o sensível, alargar a experiência e interpretar com maior rigor e de modo científico a realidade da Fisis $\left({ }^{16 \mathrm{~S}}\right)$. Daqui se colige a distinção básica entre experiência e sentir, realidade e sentir: «os objectos físicos da ciência de hoje cada vez mais se definem com maior pureza como correspondentes físicos de operações matemáticas.... sem inclusão necessária de qualquer sentir» $\left({ }^{164}\right)$. Não se pode confundir o objecto da ciência física com o objecto da percepção sensível, ligado ao sentir, pois o que chamamos «coisa», é uma ideia criada pela actividade da mente perceptiva do homem e depois negada pela mente científica. Enquanto a percepção inclui sempre o sentir, o objecto da ciência física não admite as «coisas» do nível percepcional, refere-se a actividades ou operações ideais matemáticas da experiência ideal, que é a operação matemática, sempre carecida da experimentação ou prova de contrastaria para ter entrada na Física. A operação matemática, apesar de distinta da esfera da intuição sensível, necessita da observação sensorial para ter validade no domínio da Física. Isto, porém, não invalida a diferença entre inteligível e sensível mas pressupõe-na, pois só por «dessensibilização da vivência» e "desindividualização da experiência» se cria não só o objecto científico e o seu correlativo «eu inte-

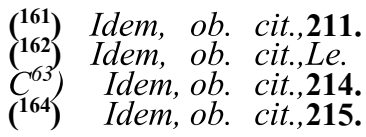


lectual», oposto ao «eu sensível», mas também a «nossa pessoa ética, aproximando-nos do Espírito e do Eu Transcendental e fazendo-nos entrar numa vida universal e unitiva» $\left({ }^{165}\right)$. O sensível é a esfera do subjectivo, quer seja o «eu sensível» quer as intencõoes sensíveis; o «real» é a região do objectivo, do dessensibilizado e desindividualizado, lugar da ciência e da filosofia, que invalida o coisismo da percepção sensível. Sérgio recusa o epíteto de «idealista» no sentido da negação da existência de algo independente da nossa psique, de uma rear lidade física, de uma Fisis $\left({ }^{166}\right)$, mas afirma um «idealismo.... de diversa índole», isto é, gnoseológico e não ontológico, pois é a existência de uma realidade física «que decide da sorte das teorias físicas através dos processos de experimentação rigorosa». Este algo, independente da nossa psique, não o pensa Sérgio como exterior à consciência, porque isto implicaria considerar também a consciência como exterior, isto é, coisificá-la e submetê-la a relações espaciais. Ora, a consciência é em si não-coisista, pois é a actividade, que, não sendo coisa nem qualquer relação espacial, «coisifica as sensações» e "submete as sensações às relações espaciais» $\left({ }^{167}\right)$. Nesta perspectiva, o mundo (o X, a Fisis) não é uma colecção de coisas mas uma actividade, que suscita na psique os dados dos sentidos, as sensações ou intuições, que são meros sinais da Actividade-Mundo mas não imagens ou reflexos seus. Por isso, a sensação é não um reflexo da Actividade-Mundo mas algo, que brota da nossa própria psique provocado por essa Actividade como sinal ou indício seu $\left({ }^{168}\right)$. Na intuição sensível provocada pelo $\mathrm{X}$ do mundo não há ainda objecto; na percepção das coisas, há uma interpretação do sentir realizada pela actividade da mente, «atribuindo um objecto à intuição sensível, transformando em 'coisa* o que era só sentir» $\left({ }^{169}\right)$. No caos confuso de sensações não ha ainda objectos nem experiência mas através de certas relações espaciais «infundimos-lhe as ideias de umas tantas coisas», gerando o nível percepcional e constituindo a experiência. A criação científica desenvolve, para além da intuição e da percepção, o sistema das relações formais, de tipo matemático, que inaugura a verdadeira cientificidade. Quer a experiência, quer a percepção ou a ciência resultam sempre da colaboração de duas actividades - a da Actividade-Mundo e a da Actividade

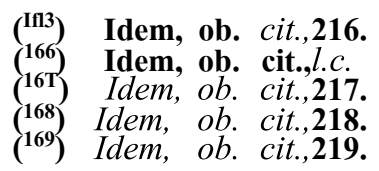


do Espírito, dentro de uma concepção dinamológica da existência física e humana, base primária da essência da cooperação. O primado da colaboração dos sujeitos a nível perceptivo permite ver na percepção normal uma «alucinação ou sonho onde temos possibilidade de introduzir coerência e onde nos sentimos confirmados pelo testemunho alheio» e na alucinação pura «uma percepção não confirmada pelos outros, pela sustentação recíproca das ideias» $\left({ }^{170}\right)$. No dinamismo da Actividade-Mundo e da Psique assenta o cooperativismo gnoseológico, que preside à criação do cosmos da percepção e do mundo científico.

Ao tratar da passagem do sentir, em que a Actividade-Mundo tem a prioridade, para a percepção do objecto, constituído pela Actividade da Psique, Sérgio fala de dois pares de ideias a que chama «relações categoriais», decisivas para a intelecção do conceito de «coisa»: a relação catégorial coisa-qualidade e a relação causa-efeito em que a «coisa» é pensada pela mente perceptiva como «causa» da sensação em nós. $\mathrm{O}$ que chamamos mundo sensível ou conjunto de coisas, diferente da Actividade-Mundo, é tecido pelos juízos de atribuição, em que o intelecto predica de algo substantivo criado pelo seu dinamismo mental, como, v. g., o céu, uma qualidade adjectiva ou sensação induzida na Psique pela Actividade-Mundo, v. g. o «azul». «E a prova bem forte de que a cúpula celeste (o Substantivo, a coisa) não é um dado do Mundo, mas uma contribuição do intelecto, é que o homem civilizado destes dias de hoje não acredita na existência da cúpula azul (do tal céu, da coisa), mas apenas na existência do sentir azul» $\left({ }^{171}\right)$. A coisa depende da mente, é uma criação sua, como a física de objectos é uma física humana mas não uma física em si. Esse algo que explica a aparência sensível, por exemplo, do azul, é não-sensível, é uma energia ou Actividade-Mundo, que não é coisa, embora só através desta se conceba.

Sendo as coisas e todas as ideias relacionais sobre elas criações da inteligência, é absurdo falar-se dos reflexos das coisas nos cérebros dos homens ou do seu aparecimento fatal, pois a sua concepção é dinâmica e livre. Ao cooperativismo gnoseológico da actividade da Psique e da Actividade-Mundo acresce agora a ideia fundamental da liberdade: «No início da criação de um saber científico, a fantasia do sábio é inteiramente livre, aventureira em extremo; é cabalmente es-

(17o) Idem, ob. eit., 218.

(') Idem, ob. eit, 220. 
pontânea, radicalmente dinâmica» $\left({ }^{172}\right)$. Formulado um problema a partir das aparências sensíveis ou sinais de mundo, o sábio «fantasia hipóteses para resolução do problema, com iniciativa que é livre, radicalmente dinâmica». A selecção das hipóteses que livremente se criam, é condicionada pelas experimentações, que servem para a contrastação ou submissão das hipóteses «à Actividade-Mundo (ao tal X misterioso), à realidade física, que não é idêntica ao sentir» $\left({ }^{173}\right)$. Da actividade e liberdade da Psique e seu princípio de inteligibilidade e da actividade radical do Mundo transparece um intelecto estruturalmente inventivo, de espontaneidade absoluta e jamais espelho passivo de algo, cujas criações são seleccionadas pela Fisis, de entre as hipóteses que lhe são submetidas nas experimentações. A realidade física não se dá ao homem nem se reflecte no seu cérebro mas tem de ser adivinhada através da combinação da "fantasia criadora inventiva com o básico postulado racional da coerência, da sustentação recíproca das formas»» $\left({ }^{174}\right)$.

Não existentes na intuição, as coisas são criadas pela Psique na percepção mas desaparecem na ciência simultaneamente com a matéria $\left({ }^{175}\right)$, sendo substituídas pelas formas ou relações absolutas, omnivalentes, universais e invariantes, válidas para todos os casos possíveis na variação infinita do acontecer sensível. Os conceitos de que a ciência faz uso, apuram-se por afastamento cada vez mais longo dos sinais sensíveis da origem, "sendo essa uma condição necessária ao físico para mais bem entender a realidade da Fisis (a realidade é uma coisa, o seu sinal é outra)» $\left({ }^{178}\right)$. O sábio reduz a matéria ao átomo e às suas cargas eléctricas mas o átomo define-se por equações ou relações constantes no modo de proceder da Actividade-Mundo, por operações do pensar matemático e não por dados da intuição sensível. Por outro lado, para a ciência física de hoje, a matéria desvanece-se, originando uma energia mensuravel bem diferente do algo perene, indestrutível e incriável com que sonhava o materialismo $\left({ }^{177}\right)$. Um eleotrão não é uma "coisa» electrizada mas uma carga eléctrica, uma espécie de actividade, manifestada através de aparências punctiformes. "Ao nível da ciência, as chamadas 'coisas' não têm existência (como não existe a abóbada ce-

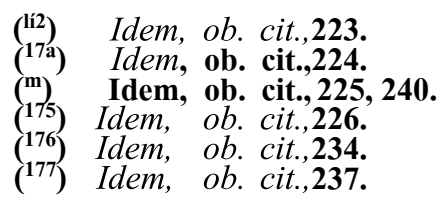


leste azul)» $\left({ }^{178}\right)$. No entanto, Sérgio confessa jamais ter duvidado de que viria a ser, no seu próprio país, o precursor de uma corrente de materialismo historico e de um movimento de interesse pela leitura económica em geral, por causa do seu ensaio sobre a conquista de Ceuta, pela orientação e intuito da Antologia de Economistas e pela sua História de Portugal $\left({ }^{179}\right)$. Contudo, não se contentou com este nível, «queria mais e melhor», pretendia «espevitar intelectos definitivamente», operar uma revolução multimoda, introduzir em tudo o racionalismo, a crítica e a problematização numa «investigação libérrima», transitando do dogma para a liberdade crítica, sem jamais se encarcerar "na cadeia mais alta de um qualquer materialismo» $\left.{ }^{180}\right)$. Sérgio aceitou «com júbilo»a honra «de precursor autêntico do materialismo histórico nas nossas letras» mas ambicionou também o papel de precursor daqueles, «que hão-de transbordar de qualquer materialismo», dos que hão-de superar o "materialismo dialéctico», dos que hão-de manter a disciplina crítica, um idealismo gnoseológico, uma pedagogia activa ou trabalhar nas planificações económicas e no cooperativismo integral, ensinando o povo a emancipar-se a si mesmo $\left({ }^{1 \mathrm{~S} 1}\right)$.

Só pela relação matemática tenta Sérgio definir o real físico e, por isso, os conceitos da Matemática e da Física libertam o homem cada vez mais das sensações, da obsessão do sensível para que ele melhor penetre na realidade física e se aproxime da Actividade-Mundo. Para o historiador como para o físico de hoje, toda a investigação se baseia no postulado da universal inteligibilidade, «que era o Bem para o Platão (no meu interpretar, claro está)», de um determinismo de direito, da existência de formas ou relações inteligíveis $\left({ }^{182}\right)$.

Os objectos não são reais, nem coisas dadas fora e independentemente do nosso pensar, pois todos os objectos estão no pensamento como ideias, são do pensamento e reduzem-se sempre a tecidos de ideias. Nós avançamos, segundo Sérgio, "de ideia para ideia», sendo a verdade não «o acordo da ideia com a coisa (porque não há o absoluto da dita 'coisa') mas «uma harmonia progressiva de ideias» $\left({ }^{183}\right)$. A partir do binário dinâmico constituído pela Actividade-Mun-

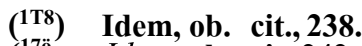

(170) Idem, ob. cit.,242.

(180) Idem, ob. cit.,243.

(**) Idem, ob. cit.,244.

(m) Idem, ob. cit., 250-251.

$\left.{ }^{183}\right)$ Idem, «Migalhas de Filosofia», 209-210. 
do e Psique, sujeito e objecto não são duas coisas que se defrontam mas duas faces correlativas de um só processo da actividade mental $\left({ }^{184}\right)$. As coisas são entrançados de ideias ou modos "como a Actividade se manifesta ao homem ao nível mental da percepção» e existem «tão-só no Todo-Uno, $o$ qual não é a coisa mas Actividade» $\left({ }^{183}\right)$.

No cume da sua actividade super-coisista, a consciência racional pura "está fora do espaço e fora do tempo», como raiz e unidade das consciências empíricas e condição de possibilidade da dessubjectivação do pensar e construtora inextensa da idealidade do espaço. O universo é algo trans-coisista, é «uma Actividade constante, uma cadeia de acções e de reacções», onde, para nosso uso operamos cortes ou rasgões pragmáticos, segundo os nossos interesses e «cada rasgão é uma coisa» $\left({ }^{186}\right)$. No contínuo percepcional, salientamos arbitrariamente objectos concretos ou coisas, segundo o interesse que nos guiar, e, por isso, as coisas não são conceitos de Kant nem formas de Platão, dado o grau de formalidade e de universalização destes mas recortes ou descontinuidades fenoménicas operadas pela mente na continuidade do aparecer, segundo os interesses dominantes. $\mathrm{Na}$ raiz das coisas há uma abstracção da mente, que as arranca ao nosso todo percepcional, construindo-as, a partir das sensações, segundo «um sistema de relações indivisíveis». Por isso, «o objecto.... construído pela actividade da mente, a partir dos dados dos sentidos, é um constrato percepcional»» $\left({ }^{187}\right)$ e as coisas comuns resultam da cooperação e do interesse comuns. O dinamismo da mente, a actividade psíquica, não se define, é «o algo primário e irredutível», é a consciência, donde Sérgio parte e de que nunca sai $\left.{ }^{188}\right)$. Por isso, tudo é visto na consciência do agente e o que se chama corpo, resulta, neste sentido, de uma operação da inteligência, de um juízo objectivador. O ser é ser consciente e «tudo é concebido em termos de consciência, tudo considerado na actividade psíquica». Este imanentismo universal e total é formulado nestes tempos, após a rejeição da negação da individuação operada por Schopenhauer: «Tudo consciência, tudo psicologia, tudo espiritual, tudo humanismo» $\left({ }^{189}\right)$.

\footnotetext{
(,84) Idem, ob. cit., 209.

(1M) Idem, «Explicações a um Catedrático de Direito», in: Idem,

$C^{6 ")}$ Idem, ob. cit., 210-211. Ensaios VII, 148.

(187) Idem, $o b$. cit., 151.

(18S) Idem, ob. cit., 154.

(1sö) Idem, ob. cit., l.c.
} 


\section{Antonio Sérgio}

Do exame da percepção e da ideia de espaça resultou, para Sérgio, a necessidade de conciliar, dentro da imanência da consciência, o finito com o infinito, o múltiplo com o uno, $\mathrm{o}$ todo com as partes, dando precedência ao todo sobre as partes, ao infinito sobre o finito, à unidade sobre a multiplicidade, pois tal é «o próprio carácter do pensamento» $\left({ }^{190}\right)$. $\mathrm{O}$ espaço como um todo dado anteriormente às partes, que parece «a essência da realidade» como «o essencialmente externo no que é externo», existe unicamente no nosso pensar e, se «o realismo das cousas» for a extensão, "sucede que a única extensão concebível vem a ser finalmente a extensão como ideia» $\left({ }^{191}\right)$. Neste contexto, propõe-se Sérgio conceber o Espírito não como «uma cousa defrontando as cousas» mas como um acto criador do espaço e gerador do binário do eu e do não-eu, que são "criaturas da actividade pensante». Esta é Ideia, Pensamento, Absoluto, Consciência Pura e Impessoal, até onde chega a redução da existência de cada um de nós $\left({ }^{192}\right)$. $\mathrm{Na}$ actividade criadora do Espírito está a unidade do eu e do não-eu, da Psique e da Actividade-Mundo, onde termina a concentração do homem sobre si mesmo. Há uma intuição da actividade do Espírito, intuição intelectual e não sensível, «que não nos dá uma cousa, mas propriamente um acto». Esta actividade está viva e actuante na «pura filosofia ocidental e moderna», que parte da aplicação da Matemática às coisas, aproximando-se da realidade do objecto «por meio de um tecido cada vez mais denso de relações intelectuais de claridade perfeita». Esta filosofia pura da actividade sofre a oposição de «uma filosofia e uma religião realistas», que «laboram sobre cousas e sobre alguéns», entravando o nosso avanço europeu $\left({ }^{193}\right)$.

No conceito sergiano de espiritualidade e de ser espiritual, patenteia-se a superação do coisismo, que pesaria sobre o realismo tradicional. A espiritualidade verdadeira é a intelectual, oposta a «certas superstições, filhas da imaginação materializadora» e persistentes nas crenças religiosas do homem de hoje. Só é espiritual aquele que sabe com toda a clareza «que as cousas exteriores não valem em si, mas só como meios de bons estados de espírito» e é, portanto, capaz «de libertar a alma das limitações individuais», dos desejos, paixões, interesses, profissão, pátria, a fim de assumir uma

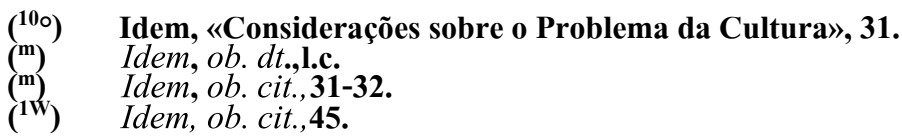


atitude objectiva e crítica e de se erguer ao ponto de vista do universal pela consideração da unidade do Todo $\left({ }^{194}\right)$. Uma funda raiz da incultura está, para esta linha de pensamento, no império da percepção externa e no «pensar sob a tirania da percepção das cousas», numa palavra, em ser realista e coisista não só quanto ao mundo externo mas também quanto «aos próprios problemas da consciência humana», como a moral, a política, a religião e a educação $\left({ }^{195}\right)$. Ser culto é ser espiritual através da libertação de toda a espécie de limitações e coisificações realizadas pelos nossos interesses, é ser «um amante férvido da liberdade», amando nos outros a «Razão e a Liberdade que representam» $\left({ }^{196}\right)$. Para o verdadeiro espiritual, «a ordem exterior da sociedade visível» é apenas um meio, jamais um fim e deve concorrer para a emancipação de todos, servindo «a ordem invisível das consciências livres». Sacrificar a liberdade à exterioridade da ordenação coisista, submeter os bens da cultura do espírito à «propaganda sectária de qualquer política» é, para o homem espiritual e culto, «uma contradição evidente e a incompreensão absoluta do verdadeiro valor». Ser espiritual, culto é ser idealista, é «acreditar que tudo que é realmente um bem, se reduz em suma ao que é um bem do espírito $\left({ }^{197}\right)$, revelado sempre na forma de uma consciência individual, é ser um infinito que escapa a si mesmo, sempre maior do que ele julga que é. $\mathrm{O}$ racionalismo místico de Sérgio exprime o cume desta libertação e concentração espiritualizadora nestes termos: "«....a verdade reside em nós, Deus em nós; o infinito em nós» $\left({ }^{198}\right)$.

Sérgio aponta na sociedade do nosso tempo quatro obstáculos ao avanço na espiritualidade, que são outros tantos índices do «coisismo» ou da cristalização limitadora do homem contemporâneo: a falsa concepção de progresso e a materialização do espírito do trabalhador; a persistência dos «espectros» ou de certas concepções obsoletas e totalmente incompatíveis com o pensar moderno $\left({ }^{199}\right)$; o pânico geral, que, no após-guerra, tirou a audácia e lucidez mental às nações europeias para buscar soluções sem abandonar as ideias humanitárias, que impuseram a Europa; a «traição dos clérigos» ou a deserção de uma parte dos escritores europeus, que

(1M) Idem, ob. cit., 33.

(105) Idem, ob. cit., 32.

(ie6) Idem, ob. cit., 39.

(m) Idem, ob. cit., l.c.

$\left({ }^{1+78}\right)$ Idem, ob. cit., $\mathbf{3 5}$.
$\left({ }^{1 M}\right)$ Cf. Idem, «Espectros» in: Idem, Ensaios I, 171-187; Idem, «Ainda os Espectros» in: Idem, Ensaios I, 191-198. 
trocaram o ideal da cultura pelo serviço dos interesses de classe, de partido, de patriotismo e de conservação social, propagandeando a mentalidade bárbara e "sacrificando a Verdade ao oportunismo da acção» $\left({ }^{200}\right)$. Estes obstáculos terão de ser vencidos através da «audácia de uma revolução profunda», que exige dos «chefes de indústria» e dos «homens de Estado» "se convençam enfim de uma vez para sempre que o homem não existe para fabricar as cousas, mas que é sim a produção que se destina ao homem». De contrário não se poderá «espiritualizar o trabalho e humanizar a faina» $\left({ }^{201}\right)$.

Sérgio viu a oposição espírito-coisa estampada na dualidade inconciliável da Modernidade: Cristo e Maquiavel, Espírito e Força, Cruz e Espada ${ }^{202}$ ). O mal europeu foi a escravização ao sensível e às crenças mitológicas e a cedência à materialização, apesar do exemplo de Sócrates, Descartes, Espinosa e Fichte $\left({ }^{203}\right)$, vítimas precoces da tradição realista ou em si mesmos ou nos seus sucessores e de vícios materializadores da imaginação do vulgo ou de filosofias pré-científicas, que classificam os factos sensíveis segundo uma hierarquia de noções abstractas. Contrário ao ideal da pura interioridade da Razão, o Antigo Testamento é, para Sérgio, o reino do materialismo e do nacionalismo, de que o Novo Testamento é a evidente ruptura, dada a sua concepção de Deus do Espírito, gerada dentro de nós pela inteligência e pelo puro amor, em diametral oposição ao Deus do Velho Testamento fantasiado pela percepcão externa como fabricante, guerreiro, imperador e carrasco $\left({ }^{204}\right)$. A mensagem de Cristo, que a «imaginação mitológica e materialista» perverte, é a afirmação da soberania do Espírito na sua fecundidade puramente interna, é «um apelo à reflexão sobre si, à consciência de sì, já lançado por Sócrates ao homem interior, cuja Razão encontra em si os seus próprios princípios reguladores. Na autonomia da interioridade do Espírito funda-se a moralidade e «no céu incorruptível da consciência» acontece a revelação interior, a única possível sem materialização ou coisismo. Desde que Aristóteles procurou na esfera imensa dos astros o Bem e a Verdade, que Platão buscara, por movimento centrípeto, dentro de si, somente Descartes partiu «do íntimo do nosso Espírito». mas volveu ao realismo e ao substancialismo escolástico. Foi Espinosa o criador de «um pensar metafísico suficientemente

\footnotetext{
D Idem, «Considerações sobre o Problema da Cultura», 41.

$D \quad I d e m$, ob. cit., 42.

$\left.{ }^{2}\right)$ Idem, ob. cit., 43.

Idem, ob. cit., 44.

D Idem, ob. cit., 45.
} 
fiel à mentalidade europeia», que é a mentalidade racionalista e a revolução kantiana representou um novo impulso para uma filosofia da consciência e da reflexão, que atingiu o seu auge na primeira fase da Filosofia de Fichte. A transgressão deste racionalismo interior corresponde à corrupção do espiritualismo cristão e o caminho a seguir é «interpretar o Evangelho à feição de Espinosa, como ruptura radical com o Testamento Antigo» $\left({ }^{205}\right)$.

Sendo a realidade para nós o nosso Espírito $\left({ }^{206}\right)$, a civilização é interior e a sociedade é um sistema de relações sociais, existentes como ideias no nosso espírito, impondo-se a redução dos problemas humanos a problemas de dialéctica do espiritual, que é a única realidade $\left({ }^{207}\right)$. O que existe, o que é, não é o mero facto, mas aquilo que o espírito, em virtude das leis da actividade própria, deve percepcionar, é um «dever ser inteligível originário», identificado com a criatividade do próprio espírito, que afirma, constituindo as coisas $\left({ }^{208}\right)$. No dogma da passiva aceitação do real, da perfeita submissão a um absoluto exterior, funda-se «a quimera dos reaccionários» e o cortejo do tradicionalismo e do conservantismo - variedades do coisismo, visado nesta afirmação de Sérgio: «Criar um objecto para o nosso espírito é como construir em cimento armado: as sensações são aqui o cimento; e as ideias, a armação de ferro», mas activa, dinâmica criadora, viva, ao contrário do que sucede na coisa-ferro $\left({ }^{209}\right)$. O pensamento único, ao pensar-se, gera, pela sua actividade, as duas «faces correlativas» — o sujeito pensante (eu transcendental, sujeito absoluto) e o sujeito pensado ou o objecto, que só existe na relação com o sujeito. Sérgio eleva a ideia de relação ao mais íntimo do Espírito, pois a relação da actividade de pensar "precede e origina os termos assim como a razão de uma progressão matemática origina os termos da progressão» $\left({ }^{21}{ }^{\circ}\right)$. A partir desta relação matricial é pensada a intersubjectividade humana ou o problema «de agluns objectos», que «nos aparecem ao espírito como outros eus (as outras pessoas)». Só enquanto correlativos do mesmo pensar se podem conceber o ele e o $e u$, pois «o ele não existe sem a existência do $e u$, o $e u$ não existe sem a existência do ele; e a sociedade, enfím, é a própria relação dessas duas ideias (da ideia do eu e da

$\mathbf{r}^{\mathbf{5})} \quad$ Idem, ob. eit,50.

(*") Idem, ob. cit.,27.

$\left.\mathbf{(}_{\mathbf{8}}\right)^{207}$ Idem, ob. cit., $\mathbf{2 8 .}$.

$\mathbf{r}^{8}$ Idem, «Notas de Política» in: Idem, Ensaios III, 224.

$\left.\mathbf{i}^{209}\right)$ Idem, ob. cit.,226.

(no) Idem, ob. cit.,l.c. 
do outro $e u$ ): é um pensamento no meu pensar....» $\left({ }^{211}\right)$. Porque o mesmo indivíduo participa sempre de sociedades diferentes (família, clube, Igreja, partido, oficina, sindicato, Estado...), Sérgio define estas sociedades, tomando por modelo «um sistema de equações simultâneas», em que o indivíduo, no seu ser empírico, é um termo dessas equações, sempre em função dos outros termos, e a actividade pensante é a ideia do sistema das equações, "que não são uma causa superior aos termos, mas tão-só a expressão das relações entre eles» $\left({ }^{212}\right)$. Desde a construção do objecto à génese da sociedade a partir da relação imanente ao pensar, o modelo da estrutura e da equação matemáticas torna-se o fio condutor do pensamento sergiano na luta contra o coisismo. A dimensão dinâmica e criadora da relação estrutural transparece da interpretação da frase de Duarte Pacheco «a experiência é madre das cousas», elaborada por Sérgio a partir do Timeu $(50 \mathrm{c})$. O elemento passivo implicado no conceito de mãe, «aquilo em que a cousa nasce» ou a sensação, não se pode isolar por ser mero produto da abstracção e, por isso, só existe pela estreita relação com o acto da inteligência, que infunde a ideia no seio da mãe-sensação, segundo o paradigma da actividade paternal. «E o filho é o objecto, a percepção, a cousa - aquilo que nasce....» $\left({ }^{21 \mathrm{~S}}\right)$, fruto da actividade de uma relação de pensamento.

A falsidade de todo o Empirismo está em conceder a experiência como essencialmente passiva, sujeitando a consciência às coisas, quando estas nos são dadas pela consciência e pressupõem na sua raiz a consciência. Pode o intelecto dividir o Todo-Uno em coisas e estas noutras coisas, «as nossas ideias só encontram ideias e, por isso, a experiência é um embate de ideias: o das ideias confusas com as ideias nítidas» $\left({ }^{214}\right)$. Daí, a verdade não é a adequação do intelecto com uma coisa em si mas o confronto de uma proposição com um sistema de outras proposições, para ver se é compatível ou incompatível com estas e o critério de verdade reduz-se obviamente à coerência lógica. Em favor deste relacionalismo ideal, será o realismo constrangido a admitir certamente que o número imaginário nos não vem do exterior, não é uma realidade, um objecto, uma «cousa», recebida passivamente de fora. «É sim um puríssimo inteligível, a mais incontestável

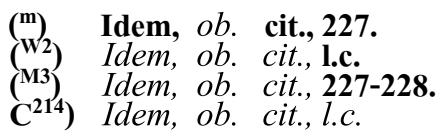


das idealidades, toda ela criada pela inteligência, sem directa intervenção da realidade sensível - dos objectos, das cousas» $\left({ }^{215}\right)$. Este puríssimo inteligível está na raiz da construção da experiência física e da criação das «cousas», havidas ingenuamente por independentes e exteriores.

$\mathrm{Na}$ crítica à passividade coisista está sempre presente o ideal da acção, da iniciativa, da aventura mental, do avanço na nossa experiência, da revolução e da audácia, em luta com a passividade ante o mundo físico e exterior e com a cedência e a abdicação no campo da justiça e do ideal humano. Colocar a matéria acima do espírito, as coisas acima da alma, sacrificar a moral a uma ordenação coisista, material, visível, é, para Sérgio, o vício verberado pelas palavras de Cristo: «A que aproveita ao homem ganhar o mundo, se ele vier a perder a sua alma?» $\left({ }^{216}\right)$ Daí, a invectiva contra aquele que descura «os problemas da dignidade da alma» e trata «as coisas como se fossem pessoas e as pessoas da família como se fossem coisas» $\left({ }^{217}\right)$, esquecendo que as obras são para as pessoas e não as pessoas para as obras e que se devem preferir as «pedras vivas» humanas às pedras mortas das obras $\left({ }^{218}\right)$, como fez Mouzinho da Silveira com suas leis de protecção e de libertação do rústico «em relação à avidez do senhor fidalgo e do clero», em contraste com as «obras públicas» de Fontes Pereira de Mẹlo, de que apenas beneficiou o capitalismo passivo $\left({ }^{219}\right)$. É que a liberdade do espírito e o amor das coisas encontram-se sempre em proporção inversa e as cooperativas como «associaçõ̃es de pessoas (de «pedras vivas», digamos) e as empresas como associações só de capitais $\left({ }^{220}\right)$ opõem-se como o ganho do espírito e o lucro coisista.

IV. O espiritualismo racionalista de Sérgio apresenta-se sob uma dimensão ética relevante. Ao contrário das escolas literárias que passam, «o ideal democrático» com o seu «sistemas de ideias» é um fim exigido pela razão, é eterno «porque deriva da estrutura da consciência humana», é «a tradução política do Evangelho» $\left.{ }^{221}\right)$, da «ideia evangélica do

(215) Idem, ob. cit., 229.

(*") Idem, «Diálogos de Doutrina Democrática», 56.

(217) Idem, «Cartas do Terceiro Homem», 129.

$\mathrm{C}^{218}$ Idem, ob. cit., 129-130.

$\mathrm{C}^{219}$ Idem, ob. cit., 208-212.

$\mathbf{C}^{220}$ Idem, ob. cit., 343. Cf. Idem, Antologia Sociológica, Pátio das Comédias, Das Palestras e das Pregações, 287.

$\left.{ }^{221}\right)$ Idem, «Diálogos de Doutrina Democrática», 7, 53, 75, 199$-200,272,329,354$. 
Reino de Deus sobre a Terra» $\left({ }^{222}\right)$. Este «socialismo etemo» é «de carácter ético e idealista, como Antero de Quental no-lo pregou», não se concretiza por qualquer reforma mecânica mas estriba «numa acção moral de todos os dias» $\left({ }^{223}\right)$. A estrutura da consciência humana temos acesso, transitando dos limites do eu empírico para a vontade geral «obscuramente exposta por Rousseau» mas claramente concebida por Kant. A vontade geral, porém, não é a vontade do Estado nem a soma aritmética das vontades individuais mas a vontade de qualquer indivíduo humano "sempre que este, para proceder, toma uma atitude de pensar objectiva, racional, geral» $\left({ }^{22 *}\right)$, subindo do indivíduo para a pessoa e coincidindo o cidadão com o homem. Pela inteligência, relaciona o homem, no mundo físico, cada parte com o Todo-Uno e, no mundo humano, integra-se a si mesmo, como simples elemento, no «todo moral», por cujas relações objectivas se rege a vontade geral, dessubjectivada da consciência sensível e capaz de erigir a razão do seu acto em lei universal $\left({ }^{225}\right)$. O que distingue o indivíduo da pessoa, a vontade particular da vontade geral, é um critério não quantitativo mas qualitativo, pois só pela transformação ou conversão do eu particular e sensível na razão autónoma, ética e social se toma o homem qualitativamente outro, capaz de ver «as coisas de uma maneira objectiva - misticamente racionalista, racionalisticamente unitiva» $\left({ }^{22 \circ}\right)$. Ao tentar definir o misticismo "pelo que se viu na Europa e no Oriente, antes e depois de Jesus Cristo e pelo que está sucedendo em nossos dias», Sérgio viu-se propenso a concebê-lo como «um máximo de Unidade do existente», capaz de ser apreendido directamente por meio de um processo, que está para além da actividade do processo discursivo. Essa Unidade, porém, é visada, de modo conceptual e discursivo, pela ciência e pela filosofia e «sentimentalmente vivida» pelo misticismo, de tal modo que «o misticismo e o racionalismo seriam revelações de uma só tendência: a da afirmação da Unidade» $\left({ }^{227}\right)$. Esta Unidade pode ser reconhecida pelo «místico oriental» e pelo «europeu racionalista» na roupagem artística «do irmão sol, da irmã água, do irmão fogo, dos irmãos pás-

("2) Idem, Sobre o Espírito do Cooperativismo (Lisboa 1958), 10. Idem, «Democracia», 103.

$\left({ }^{22 *}\right)$ Idem, ob. cit., 88.

$\mathbf{C}^{225}$ Idem, ob. cit., 88-90.

$\left.{ }^{226}\right)$ Idem, «Jornada Primeira» in: Idem, Antologia Sociológica.

Pátio das Comédias - Das Palestras e das Pregações, 249-250.

$\left({ }^{22 \mathrm{~T}}\right)$ Idem, «Sobre Cristianismo e Cristãos, Verdadeiros e Falsos» in: Idem, Ensaios VI (Lisboa 1980), 189. 
saros, da irmã terra, das irmãs estrelas» $\left({ }^{228}\right)$. O pensamento experimental não esgota a esfera do pensamento e, por isso, na estrofe lírica, no olhar amante, na intuição do génio ou no arroubo místico «há um desejo de unidade e de ordenação, que é a norma superior da inteligibilidade» e, entre os instintos e as paixões da vida humana, «avulta o instinto da unidade, a paixão do universal, a ânsia de subir ao nível do Espírito». Ciência e moral, razão científica e razão valorizadora unem-se, terminalmente, na Razão como valor supremo e «ápice do útil, do vital, do sentimental, do compreensível». Esta Razão última ou ideal de harmonia íntima é, para Sérgio, a tradução do Bem platónico, raiz de toda a idealidade e dos casos especiais das normas do entendimento $\left({ }^{229}\right)$.

Para se compreender, porém, a «atitude moral» de S. Francisco de Assis, Sérgio solicita que se abstraia o sermão aos pássaros do sistema teológico a que está unido e se compare com «o sentimento religioso que anima a Ética» de Espinosa. O resultado será concluir que a Unidade do ser é expressa por Espinosa de modo científico e por S. Francisco numa «forma propriamente artística» e «temamente poética perante as coisas» $\left({ }^{23 \circ}\right)$. No humanismo «poético e sorridente» de S. Francisco e filosófico de Espinosa vê Sérgio «o pendor.... a não levar as coisas propriamente humanas para fora do âmbito da consciência do homem, mantendo nesta as questões morais» $\left({ }^{231}\right)$. Comparada com esta exigência de Unidade racional, que é a raiz mais profunda do humanismo, «a pretensa irreligiosidade de muito bom Europeu é de essência religiosa ou de carácter místico (racional e místico)» $\left({ }^{232}\right)$, como, aliás, a verdadeira intelectualização da doutrina evangélica se vislumbra nas concepções de Espinosa. Sob o modelo da razão como princípio da unidade unificante, o sentido de uma civilização cristã é o de uma civilização racional com «identidade de imperativos morais» $\left({ }^{233}\right)$, onde refulge o «Deus da inteligência» ou o Acto dos actos de pensamento objectivo $\left({ }^{24}\right)$. O «nosso anseio de inteligibilidade» ou o «dever ser inteligível»é paralelo ao «dever ser moral» e desta tendência unificante, ordenadora e dessubjectivadora comum, é que

\footnotetext{
(228) Idem, ob. dt., l.c.

(229) Idem, «Educação e Filosofia» in: Idem, Ensaios I, 151. sos», 190

${ }^{23 \circ}$ ) Idem, «Sobre Cristianismo e Cristãos, Verdadeiros e Fal-

$\left.C^{l}\right) \quad$ Idem, ob. cit.,l.c.

$\left({ }^{2} 2\right)$ Idem, ob. cit.,182.

$\mathbf{C}^{233}$ Idem, ob. cit.,194.

$\mathbf{C}^{234}$ ) Idem, ob. cit.,201.
} 
provém a ciência e a moral, o saber do que é e daquilo que deve ser. Por isso, «a unidade legal do múltiplo, princípio da consciência, é o postulado comum do cientista e do moralista» $\left({ }^{235}\right)$. Neste princípio radica o «parentesco fraterno da ciência e da moral»» e a necessidade do ensino humanista das ciências, cujo esquecimento redundou nos vícios opostos do abstracto intelectualismo, que reduz a razão à faculdade da abstracção, e do exagerado sentimentalismo, «que omite na vida dos instintos o instinto racional» $\left({ }^{236}\right)$. A verdadeira liberdade, longe de se identificar com a do impulsivismo romântico, é a do racionalismo ético, a do autodomínio ou da submissão do $e u$ biológico ao eu racional, objectivo e universal e, por isso, ao contrário do socialismo naturalista e empírico, o socialismo rigorosamente idealista, ético e apriórico, não se fundamenta no que ele comprova que é mas naquilo que pensa que deveria ser» $\left({ }^{237}\right)$. Em linguagem axiológica, isto significa que "os valores só serão valores, se houver um valor incondicionado, base de todos os outros, que não preste contas no tribunal do facto, que seja ele mesmo o juiz supremo». Os factos não servem de critério de valor mas é a próprio consciência que valoriza, acima de qualquer determinismo, pois é soberana a vontade de escolher $\left({ }^{238}\right)$. Logicamente, Sérgio critica a moral sociológica de Durkheim, Lévi-Brühl e outros por ter definido a moralidade «como a subordinação dos indivíduos aos preceitos da sociedade empírica (da sociedade existente, considerada uma coisa) na qual residiriam toda a origem e todas as normas da moralidade». A subordinação da moralidade à sociedade da experiência induziu Durkheim a reduzir a noção de bem moral à de normalidade, definida estatisticamente como facto médio. Sérgio pergunta: que sociedade nos impõe a lei moral, a do sindicato, a do bairro, a do clube, a do Estado, a da Humanidade? A resposta não pode ser senão a da Humanidade, entendida não segundo a sua extensão real, pois «nunca a Humanidade se concentrou para exprimir a sua lei» mas segundo a sua compreensão ideal, isto é, de acordo com a «faculdade de se elevar ao Espírito» e as necessidades estruturais da consciência intelectual, não da sensível, de cada homem« $\left({ }^{239}\right)$. A história

$\left({ }^{235}\right)$ Idem, «Educação e Filosofia» in: Idem, Ensaios $I, 140$.

$\left.C^{6}\right)$ Idem, ob. cit., l.c.

Idem, «Apêndice, Alocução aos Jovens (Excerto)» in: Idem, Antologia Sociológica... 169-173; Idem, «Sobre o Socialismo de Oliveira Martins» in: Idem, Ensaios VIII (Lisboa 1974), 187.

(238) Idem, «Explicações a um Catedrático de Direito», 153-154.

(239) Idem, «Educação e Filosofia», 143-145. 
dá-nos a contraprova desta conclusão no frequente antagonismo entre a moralidade e a sociedade empírica, como foi o caso da paixão de Cristo, o da condenação de Sócrates ou a realidade quotidiana do misantropo, que é o insociável por excelência $\left({ }^{240}\right)$. É que a moralidade como «uma sociabilidade.... ideal, racional» pode opor-se à sociedade empírica, em virtude da sua verdadeira ordem espiritual, em que a todos os indivíduos é reconhecido o mesmo valor e entre eles se estabelecem relações de reciprocidade, as regras são verdadeiramente universais e sem contradição no seu conjunto e os fins em que se inspiram todos os preceitos, são também universais. $O$ indivíduo que ascende a este nível racional, tem «o direito de contraditar, em nome da sociabilidade espiritual ou ideal, a sociedade empírica que o descontenta» $\left({ }^{241}\right)$. $\mathrm{O}$ indivíduo, neste caso, pela razão, pende a estabelecer uma harmonia, uma ordem, uma coerência ou unidade não só nas representações mas em toda a vida da sua mente, não só na natureza mas também nos homens, entre os objectos e entre as vontades. "Satisfazer esta tendência nas relações entre os quereres, no campo das representações sociais e dos sentimentos que lhes correspondem, - tal é, propriamente, o objecto da moral» $\left({ }^{242}\right)$. A distinção basilar entre sociedade empírica e sociedade ideal permite definir a moralidade como obediência à sociedade concebida não como uma realidade coisista exterior mas como Ideia, que é a verdadeira expressão da racionalidade ou espiritualidade do indivíduo. $O$ vício da Escola Sociológica esteve sempre na concepção da «sociedade como uma coisa da experiência, um facto, um dado e não uma ideia» $\left({ }^{243}\right)$.

A partir dos princípios fundamentais da consciência («Se suprimirdes a consciência - abismai-vos no Coisa Nenhuma: no Nada») e da relação («o real é a unidade e correlatividade do objecto e do sujeito, do eu e do não-eu na actividade de um Eu que os concebe a ambos»), Sérgio concebe a sociedade sempre relativa a um sujeito pensante, «sempre como ideia numa consciência» ou como «um sistema de relações sociais» na consciência e o indivíduo sempre numa relação com sociedades, a mais imediata das quais é a sociedade familiar. A consciência do eu implica a relação de alteridade ao não-eu, entendido não só no sentido do objecto mas também do «ou-

$\begin{array}{ll}\left.\mathbf{C}^{\mathbf{2 4 0}}\right) & \text { Idem, ob.cit., } 145 . \\ \left({ }^{(6)}\right) & \text { Idem, ob. cit., } 146 . \\ \left({ }^{\mathrm{M} 2}\right) & \text { Idem, ob. cit., } 136 . \\ \left.\mathbf{C}^{243}\right) & \text { Idem, ob. cit., } 146 .\end{array}$ 
tro-eu, do sócio, do semelhante, do companheiro». Privilegiando a relação ao outro-eu, Sérgio considera-a «uma das tendências mais profundas, uma das determinações essenciais da actividade da nossa psique»» $\left({ }^{244}\right)$. Sob o primado da consciência e da categoria da relação, a sociedade e o indivíduo estão no pensamento como ideias, são ideias que se sustentam por mútua referência. Sérgio chama-lhes os «dois momentos inseparáveis da dialéctica do nosso espírito» e da sua lei de unidade, que é unidade da consciência e unidade do universo, de que participa o nosso «eu profundo» $\left({ }^{245}\right)$. A conciliação deste ideal de sociabilidade com o pensamento experimental exige que as ideias não visem apenas resultados pragmáticos mas respondam às aspirações da consciência e melhorem a vida também num sentido espiritual. De contrário, o valor da ideia depende do êxito material do organismo, arvorado em fim e resultado das aspirações e valores ideais, o que, por outras palavras, significa que o valor da ideia é ilusório, pois dirige-se a um porto e entra noutro, quer uma coisa e consegue outra, transcende a matéria mas permanece material, supera o mecanismo mas continua mecânico $\left({ }^{246}\right)$. Acabar no materialismo é suicídio e, por isso, o «élan da psique» é mental, isto é, conduz a uma ética racionalista $\left({ }^{247}\right)$. Ao contrário do que pensam os psicólogos que elevam a imitação a facto social fundamental, Sérgio coloca-a ao nível pragmático do «mais importante instrumento do desenvolver da vida psíquica», pois o facto básico não é a imitação mas a tendência a participar num intercâmbio de vida psíquica, fundado num Eu-Ideia, modelo para o educando e para o educador ou legislador e justificação da acção ética ou tendência para a harmonia superior perfeita entre a ideia do eu e a dos outros $\left({ }^{248}\right)$. Este paradigma do Eu-Ideia, não pode permanecer lei abstracta mas deve plasmar-se em feitos e atitudes de uma personalidade que nos sugestione. Assim, «o instrumento por excelência na moral cristã não é uma tábua da lei com suas regras mas a imitação de Cristo e dos seus santos; na moral estoica, o imitar os heróis desta doutrina; na moral patriótica, o imitar Nun'Alvares ou Joana de Arco ou Guilherme Teil» $\left({ }^{249}\right)$. Pouco importa para Sérgio que os santos ou os heróis tenham realmente sido o que imaginamos ou mesmo

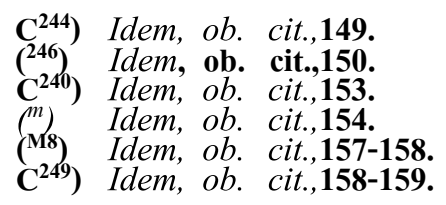


que tenham existido. O importante é que o ideal se traduza pela imagem viva de uma pessoa, que permita ao cidadão ser legislador e súbdito e ao educando mestre e discípulo, imitado e imitador. Este ideal deve presidir à vida profissional, educadora por excelência, sobretudo pela possibilidade de cooperação para o bem comum, que lhe é facultada e em que 0 indivíduo, sem contradição, é cada vez mais socializado e individualizado $\left({ }^{250}\right)$. Não há qualquer diminuição da autonomia individual, visto que o indivíduo não é sujeitado a uma sociedade realizada mas é exercitado na racionalização de uma sociedade e nisto consiste a sua autonomia. «Livre é aquele a quem é dado, pelas condições da sua existência, o ser agente de racionalização, contribuindo por sua parte para um progresso na legalidade, para o advento de uma maior justiça....» $\left({ }^{251}\right)$ - Esquecer este fim primordial da vida profissional, da educação e da ciência é continuar o cadaverismo, a passividade de museu, o reino das curiosidades. Destas premissas se deduz o «grande absurdo» de buscar no desenvolvimento e difusão da ciência a panaceia para todos os males e de reduzir a moral à difusão da ciência, chegando ao arrojo de pensar que todos os problemas humanos se deslindam pela biologia e pela classificação zoológica $\left({ }^{252}\right)$. Obedecendo à vocação pedagógica do seu espírito, Sérgio denuncia os efeitos desta miopia científica nos programas da educação. Eliminada a concepção moral, a educação converteu-se na divulgação progressivamente avolumada dos resultados científicos segundo o ideal de uma pedagogia de quantidade, quando os valores pedagógicos residem na unidade, na concentração, no espírito crítico e na visão profunda do essencial. Separada da moralidade, a ciência positiva ameaça transformar-se numa forma superior de força mais perigosa do que a força bruta, a que Sérgio opõe «uma pedagogia de acção social, o conceito de trabalho segundo as linhas da cooperação», garantindo deste modo uma base à reforma da educação moral da mocidade $\left({ }^{253}\right)$. A acção social é a acção cooperativa em prol do bem comum e introduzi-la na escola «será a maneira de se conciliar, no mesmo processo educativo, o desenvolvimento ético com o científico, a quantidade com a qualidade, a liberdade com a disciplina, - assim como a política democrática

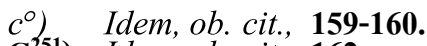

$\left.\mathbf{C}^{251}\right)$ Idem, ob. cit., 162.

$\mathbf{C}^{\mathbf{2 5 2})}$ Idem, «Ciênciae Educação», 100.

${ }^{(253)}$ Idem, ob. cit., 113.
} 
com os anseios do humanismo, a matéria social com as aspirações da consciência» $\left({ }^{254}\right)$.

Não é na "sabença» ou acumulação de conhecimentos meramente recebidos, sem a actividade investigadora e crítica e a objectividade própria do criador científico que reside o valor humano ou o aperfeiçoamento das consciências, pois a «sabença» «tende, pelo contrário, a perverter as almas do comum, onde não reina soberanamente o instinto da moralidade» $\left({ }^{255}\right)$. Coincidindo com a crítica de Rousseau e explicitando-lhe o pensamento, Sérgio reafirma que a "sabença» só por si e aplicada ao comum da humanidade não só não é educativa senão que francamente corruptora e com Rousseau conclui que a ciência ou a inteligência do saber científico não pode fundar uma moral $\left({ }^{256}\right)$. Consciente da sabença académica, do eruditismo sem sentido e do saber armazenado da convencida inteligência portuguesa, Sérgio considera as realidades com que Rousseau se debateu, "semelhantes àquela em que nos debatemos» e pinta um quadro agudamente crítico, que faz pensar o intelectual consciente, despe das penas roubadas os que vivem cientificamente da investigação alheia e aponta a nudez dos que, incapazes de verdadeira ciência, se adornam de pormenores e arroubos de eruditismo: «É pensar na cultura da sua época, já rancida; no materialismo pesadão e dogmático dos Holbachs e na sarcástica estreiteza desses homens, que haviam substituído pelo 'esprit' as mais fecundas e inspiradoras seivas, as mais vivas e humanas faces da humana consciência; é advertir nos petimetres dos nossos dias, nos Bouvards e Pécuchets que aí pululam, encéfalos engordados com bolota fácil em livrecos simplórios de vulgarização barata, é cuidar nos grão-mestres da sarabanda, sacerdo*tes do Poder Espiritual nas suas Academias para todos os cérebros,- - com crachás e farda como outrora os duques, tropa de gala e música como outrora os ídolos. Os grão-lamas entram, procissionalmente.- e lá dentro, ébrios do incenso das gloriolas e dos perfumes das madamas, clamam que a sua ciência é uma Deusa, e a sua palavra um Dogma, e a sua tertúlia um Templo.... E as músicas tocam, as espadas tinem, as carecas brilham, voluptuosamente....» $\left({ }^{257}\right)$.

Não só a ciência e a educação mas também as medidas económicas só pela sua fundamentação ética se podem con-

$\begin{array}{llll}\left.\mathbf{C}^{254}\right) & \text { Idem, ob. } & \text { cil.,,114. } \\ \left.\mathbf{C}^{\mathbf{2 5 8}}\right) & \text { Idem, ob. } & \text { cil.,119. } \\ \left.\mathbf{C}^{\mathbf{2 5 6}}\right) & \text { Idem, ob. } & \text { cit., 123. } \\ \left.\mathbf{C}^{\mathbf{2 5 7}}\right) & \text { Idem, ob. } & \text { eil.,121. }\end{array}$ 
siderar humanas. As principais razões de uma reforma agrária, como, aliás, de todas as reformas de natureza económica, são sempre, para Sérgio, as razões morais, as razões de justiça. Acima do aumento de produção e de quaisquer resultados materiais estão a paz, a alegria, a felicidade, a beleza da vida familiar, embora nenhum destes resultados seja ainda o essencial e o fim supremo, que residem apenas na «dignidade da pessoa humana, inconciliável sem a liberdade» $\left({ }^{258}\right)$. Para libertar os pobres e assegurar a dignidade de todos os homens e o máximo de consciência do cidadão é que Sérgio propõe um mínimo de propriedade adquirida e a prudente socialização dos principais meios de produção não pelo Estado mas por cooperativas. Os melhoramentos materiais são apenas factores de melhoramento interior e a emancipação económica serve a emancipação moral, como instrumento da liberdade do espírito ( ${ }^{259}$ ). A Democracia Cooperativa, que realiza esta emancipação moral, exige a eliminação da ideia do lucro e da guerra económica ou concorrência, porque, de contrário, não desponta a liberdade do trabalhador e a sua participação na direcção económica $\left({ }^{260}\right)$ nem tão-pouco se realiza «a ideia de civilização interior, que vemos dominar nos Evangelhos: a veracidade, a fraternidade, a igualdade, o amor ao próximo como a nós mesmos» $\left({ }^{261}\right)$.

$\mathrm{O}$ conceito de melhoramento tem para Sérgio um conteúdo ético, pois as obras são «coisas absolutamente odiosas quando não subordinadas ao amor da Grei, à justiça social, à busca de iguldade, ao bem espiritual e material dos pobres» $\left({ }^{262}\right)$, quando são pedras mortas erigidas em valores absolutos contra as pedras vivas, que são as pessoas, quando a natureza e a técnica de construção não são postas ao serviço da unidade humana. O critério da expropriação de terras para construções de melhoramentos deve ser humanista, multilateral, compreensivo e unitário, como todo o critério, que respeite a administração de um povo $\left({ }^{263}\right)$.

As relações de produção não se podem eximir ao imperativo ético, porque, "além das condições só técnicas, da alçada dos engenheiros e dos financistas hábeis», há requisitos de natureza humana $\left({ }^{264}\right)$, que privilegiam as 'pedras vivas'

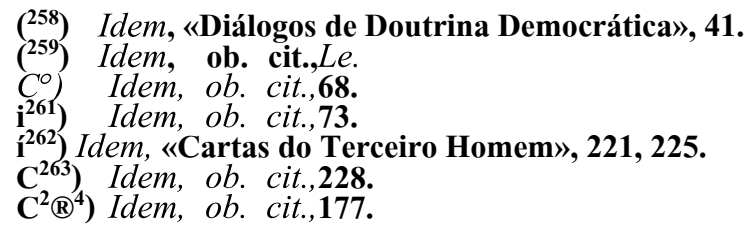




\section{Antonio Sérgio}

consumidoras, as 'pedras vivas' da pesca, as 'pedras vivas' dos agros. Urge «abolir o sacrifício das 'pedras vivas' do povo às engrenagens parasitárias que as têm asfixiado até hoje e.... ampliar - à luz social deste século - a obra libertadora de um Mouzinho da Silveira». Com um aumento de produção, neste caso, benéfico, será possível concretizar a expressão paulina: «Desta sorte.... não somos filhos da escrava, mas da livre, com cuja liberdade Cristo nos fez livres») (Ad Gal. IV, 31) $\left.{ }^{205}\right)$.

À luz do conceito ético de liberdade, Sérgio aceita a definição de educação como a arte de emancipar os homens e propõe que a obra política seja também uma arte de emancipar os homens, cabendo ao grande político e ao grande pedagogo trabalhar por se tornarem dispensáveis, já que é escopo de ambos treinar o povo para se governar a si mesmo, com o mínimo de intervenção de quaisquer políticos $\left({ }^{26 \mathrm{G}}\right)$. Em termos pedagógicos, «a boa política é a de educar a gentinha para resolver por si própria os seus problemas mais graves, para se libertar por si mesma dos seus maiores aperreios, graças à cooperação»» $\left({ }^{287}\right)$. A emancipação, pela cooperação, dos alunos na escola, liquidada pelo figurino paramilitar para a educação dos jovens, deve preferir a modelos guerreiros e militares, por essência heterónomos, os paradigmas da vida civil dos concelhos antigos, dos municípios modernos e das cooperativas de hoje, em que perpassa a força e o ideal da liberdade. Neste contexto, Sérgio subscreve a afirmação de Antero de Quental de que «a grande revolução.... só pode ser uma revolução moral» ( ${ }^{268}$ ) e propõe, como ideal, aos 'seareiros' uma «conversão total, - e uma conversão, que se não faz de uma vez, que é de dia a dia», porque a obra mais difícil para o homem é libertar-se das limitações que o cingem, é tender sem fim para o universal e eterno, que é o Espírito $\left.{ }^{269}\right)$.

E numa intenção ética que Sérgio interpreta a alegoria da caverna como superação da atracção do sensível, a que o homem volta as costas, a fim de criar a sua personalidade ética ${ }^{27 \circ}$ ). $\mathrm{O}$ postulado basilar da ciência não é a fé na previsibilidade de todos os factos do mundo mas o postulado da

(*’) Idem, ob. cit., 184.

$\left.i^{x}\right)$ Idem, ob. cit., 187.

("') Idem, ob. cit., 189.

x) Idem, «Da Ilusão Revolucionária de Antero» in: Idem, Ensaios V (Lisboa 1973), 129.

(*9) Idem, «Sobre Cristianismo e Cristãos», 211.

(TM) Idem, «Notas de Esclarecimento», 214, 216. 
inteligibilidade universal das coisas, a que «Platão dava o nome de Bem» ${ }^{271}$ ), portanto uma inteligibilidade de carácter ético. E anunciado o triunfo do Bem no mundo, sob o nome de Justiça, «não por uma previsibilidade como a da Física Antiga» mas pela esperança na «tenacíssima ideia» de Justiça, «escrita a tinta indelével no livro de fogo da consciência humana» $\left({ }^{272}\right)$. O postulado da maior justiça entre os homens e da inteligibilidade universal é uma afirmação «de teor radical e bem íntimo, que constitui para a minh'alma a própria condição de existir», é o modo sergiano radical de se sentir no mundo e na história, num originário encontro consigo mesmo: «Eis o que topo em mim mesmo: uma postulação da consciência; uma fé na inteligibilidade, na razão do homem, na ascensão ao Espírito» $\left({ }^{273}\right)$. Por isso, procurou Sérgio analisar os obstáculos à espiritualidade $\left({ }^{2}{ }^{\dagger}\right)$ e preferiu o «espiritualismo estreme» de Platão «à esfera astral», onde Aristoteles situou «o Bem, o templo da Verdade, o céu da Ideia» $\left({ }^{275}\right)$. O Amor do Banquete de Platão é, nesta linha interpretativa, o amor pedagógico, de carácter ético, pois o amor do educador pelo seu educando visa "auxiliar o discípulo no caminho dialéctico da ascensão moral» $\left({ }^{276}\right)$. Não menos importante é, para Sérgio, a lição da República de Platão, consignada na afirmação sintética de que «não podemos contemplar as verdades eternas sem sentirmos o desejo de as realizar, de suscitar pessoas que se assemelhem a elas», pois, neste pensamento, está contida a essência do amor pedagógico $\left({ }^{277}\right)$. O esforço por um ideal, que define a Democracia, deparou com um escolho de natureza moral, que mais duramente tem travado a sua realização: «é que a educação, até hoje, continuou a fazer-se nas escolas públicas segundo os princípios do absolutismo» $\left({ }^{278}\right)$. Os processos escolares domesticam os jovens para serem súbditos, quando o essencial na educação é criar a mentalidade do cidadão consciente, capaz de progredir democraticamente. Fiel ao ideal ético do ensino, Sérgio propõe como primeiro passo a libertação do aluno: «ele há-de ser livre nos seus estudos, e livre no governo da sociedade escolar; e o ensino, em qualquer disciplina, não há-de ter por

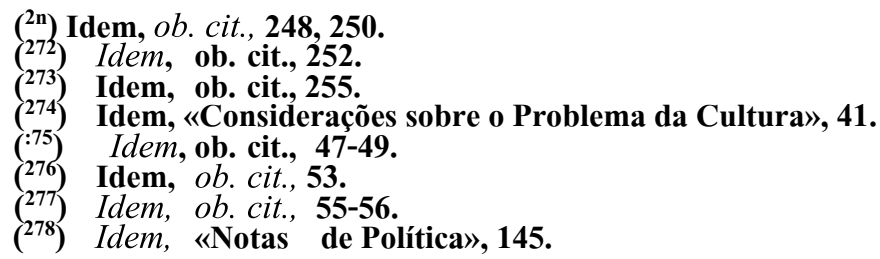


objecto o transmitir doutrinas, conhecimentos, noções, mas formar a mentalidade experimental e crítica, revolucionária, único caminho para o verdadeiro saber» $\left({ }^{279}\right)$. Só a reforma da educação pode tornar efectivas as instituições políticas e a escola pública tem de cooperar quotidianamente com o jornal diário, a propaganda e o livro num esforço contínuo de criação social, que responda ao ideal de sociedade, «que é uma cousa viva, renovadora, espiritual, dinâmica e não uma matéria que se conserve por sì» $\left.{ }^{280}\right)$.

$\mathrm{Na}$ mesma intenção ética, travou Sérgio luta constante com o «sensualismo, o empirismo, o instintivismo, as apologias do inconsciente e do subconsciente» e definiu o seu «idear lismo racionalista e crítico», o seu «intelectualismo cem por cento» $\left.{ }^{281}\right)$. A categoria fundamental de actividade significa para ele «energia mental, acção espiritual» da consciência, oposta a paixão e às deslocações materiais do movimento. Sem actividade mental, sem esforço consciente, o bem não é verdadeiro bem e neste princípio considerou-se Sérgio de acordo com a doutrina de Cristo segundo a qual o reino dos céus padece força e só os violentos o arrebatam (Mat. XI, 12) e com o ditame de S. Tiago Apóstolo de que a fé sem obras é morta (Ep. II, 17). Para o seu dinamismo ético, «o verdadeiro bem é uma conquista da alma e não uma passiva recepção do acaso».

A superioridade axiológica da actividade sobre as coisas significa simplesmente que os valores primários são os da consciência e que os fins exteriores, as coisas, a matéria não passam de meios ao serviço da vivificação interior do homem, da ordenação do psíquico e do objectivo ético $\left({ }^{282}\right)$.

A concentração ou movimento centrípeto pelo qual o homem se interioriza, é a recuperação racionalista da ideia metafísica de acto como entrada dentro de si, que, no Ocidente, caracterizou a filosofia do Espírito, desde a reminiscência platónica, a abstracção do intelecto agente aristotélico, a iluminação augustiniana, o «cogito» de Descartes, a analítica transcendental e a consciência moral de Kant, a intuição de «Thathandlung» de Fichte, a experiência como espírito de Hegel, a redução fenomenológica de Husserl. Este recolhimento do homem em si mesmo não conduz, para Sérgio, a uma realidade transcendente, que fosse «intimior intimo meo»

("•) Idem, ob. cit., 146.

$\mathbf{C}^{280}$ ) Idem, ob. cit, i.c.

('m) Idem, «Sobre Cristianismo e Cristãos», 205.

$C^{2}$ ) Idem, ob. cit., 206. 
mas permanece, como ideia, simplesmente dimensão de infinitude da imanência da consciência humana.

V. Como idealista crítico empenhado na emancipação do homem, que a autoridade tutelava e o peso coisista da realidade submetia, Sérgio postulou o fundamento de uma inteligibilidade de tipo ético, que recolhia a herança agatológica de Platão, da Ética de Espinosa, da Razão Prática de Kant, da Doutrina da Ciência de Fichte. Nesta reactivação do ideal do Iluminismo com o intuito de responder a problemas candentes do séc. XX, Sérgio realiza uma secularização do pensamento na sua globalidade, ao mesmo tempo que se compromete inteiramente com o século, assumindo a tarefa de realizar a idealidade dos seus valores. Secularização não tem aqui o sentido negativo de expropriação de um património, injustamente extorquido ao seu legítimo proprietário religioso mas significa o nascimento do mundo enquanto mundo, do homem enquanto homem e, portanto, dos diversos domínios da razão, não contra mas por influência positiva do próprio Cristianismo $\left({ }^{283}\right)$. Neste caso, a autonomia e a libertação do homem, nas diversas esferas da sua realização, não contradizem mas são, pelo contrário, condições de possibilidade exigidas pela própria encarnação histórica do Cristianismo. Nem todos, porém, os que defendem os justos motivos da secularização, eliminam da emancipação humana uma raiz incondicionada real, que transcende e funda os anseios mais profundos de libertação humana ${ }^{284}$ ). Para esta atitude, o ser não pode ser concebido a partir de um modelo coisista, sempre presente no pensamento de Sérgio, mas segundo um paradigma haurido da prática humana da decisão e da liberdade, isto é, do homem como pessoa $\left({ }^{285}\right)$. Rejeitado, porém, todo o realismo como um coisismo, abriu-se a Sérgio apenas a via da imanência da consciência e da idealidade, onde tudo é idealmente humanizado, porque tudo é reduzido à ideia e à actividade última do Eu-Espírito, origem, como em Fichte, da distinção do $e u$ e do não-eu. À secularização de Sérgio não só foi possível realizar na autonomia humana apelos saídos das mais profundas exigências do Cristianismo, como hoje se reconhece

passim.

$\left({ }^{283}\right)$ M. B. Pereira, «Iluminismo e Secularização», 483-500.

${ }^{(284)}$ Cf. H.H.-Schrey, Hrsg., Saekularisierung (Darmstadt 1981)

${ }^{(285)}$ H. Muehlen, Die abendlaendische Seinsfrage als der Tod Gottes und der Aufgang einer neuen Gotteserfahrung ${ }_{2}$ (Paderborn 1968) passim . 


\section{Antonio Sérgio}

na Teologia da Secularização $\left({ }^{286}\right)$, mas também transformar em simples ideal impessoal e universal da consciência a Liberdade Pessoal criadora do Velho e do Novo Testamento, reduzindo a Teologia a uma Antropologia, de carácter eminentemente social, racional e ético. É neste sentido que o neo-iluminismo de Sérgio é uma interpretação racionalista e crítica do fenómeno da secularização.

Um dos modos históricos de reduzir Deus a uma dimensão da consciência humana é convertê-lo numa ideia, como fizera Kant, sem postular qualquer Transcendência na esfera da praxis nem manter a adesão pela fé a um Deus Revelador. Assim, para Sérgio, Deus é «uma ideia imenșa que será talvez.... a ideia humana superior e eterna». É uma ideia de grandeza espiritual estreme, que se revela e impõe ao puro espírito e não a força que domina os corpos, é uma Bondade nua, um puro Inteligível, uma Beleza inerme e não uma divindade física ou o Deus omnipotente e regedor dos átomos $\left({ }^{287}\right)$. Retirada do espectáculo do mundo físico ou do reino microcósmico do átomo, a ideia de Deus, como ideal de bondade, inteligibilidade e beleza preside, pela sua superioridade, ao mundo das relações inteligíveis da consciência humana. Como ideal da Razão, a ideia de Deus-Espírito exige que o homem pela ciência, à maneira de Galileu, se desprenda das aparências sensíveis e lhe preste culto na interioridade espiritual da verdade racional. A Inquisição condenou Galileu «à pena de calar a verdade - a verdade pura, demonstrável e demonstrada.... Deus é Espírito, diz o Evangelho, e é necessário que aqueles que $\mathrm{O}$ adoram, $\mathrm{O}$ adorem em Espírito e em Verdade» $\left.{ }^{288}\right)$. Ora, o Deus «a que nos conduz uma maior ciência», não é «o Deus de Abraão, o Deus dos Teólogos, o Deus dos Exércitos» mas «o Deus da Inteligência», o «Acto dos actos do pensamento objectivo», o Deus dos verdadeiros filósofos $\left({ }^{289}\right)$. Este «Deus da Inteligência» é uma dimensão excelsa da consciência humana, sempre em excesso sobre si mesma, pois «a grandeza verdadeira é a que se não pode medir; capacidade infinita é a do que se não pode encher. Segundo o filósofo (Lagneau), o homem é um infinito que se escapa a si mesmo, sempre maior do que ele julga que é.... Assim, a verdade reside em nós; Deus em nós; o Infinito em nós....» $\left({ }^{29 \circ}\right)$. Na realização antropológica da ideia de Deus

$\left({ }^{28 €}\right)$ H. H.-Schrey, ob. cit., 173-391.

(MT) A. Sérgio, «Sobre Cristianismo e Cristãos, 212-213.

$\left(\begin{array}{l}25 s \\ )\end{array}\right)$ Idem, «O Reino Cadaveroso», 33.

(289) Idem, «Sobre Cristianismo e Cristãos», 201.

(20) Idem, «Considerações sobre o Problema da Cultura», 35. 
está a essência da cultura, porque o homem culto, ao procurar ser objectivo em relação às coisas, a si mesmo e aos outros, passa do sensível ao inteligível, do confuso à plena claridade das relações mentais, isto é, ao Pensamento onde as coisas e as outras pessoas residem como ideias $\left({ }^{291}\right)$. O sentido último da investigação científica é a realização de uma verdadeira cultura ou da ascensão do intelecto ao nível divino, ao cume da divinização da nossa mente $\left({ }^{292}\right)$. O Pensamento terminal é absoluto e impessoal, gerador do binário do eu e não-eu $\left({ }^{293}\right)$, sem o mínimo vestígio de transcendência, a que nos unimos mediante as "condições do juízo verdadeiro», uma vez libertos da representação sensível, «o maior pecado do pensamento humano»». ( $\left.{ }^{294}\right)$. Esta via de dessensibilização da vivência e de desindividualização da experiência conduz ao «Espírito» e ao «Eu Transcendental», «fazendo-nos entrar numa vida universal e unitiva» $\left({ }^{295}\right)$. Ao comentar um passo da conferência de Radhakrishnan sobre Tagore em que se afirmara ser impossível compreender o humano sem primeiramente perceber o divino, Sérgio afirma peremptoriamente que só o humano se pode achar directamente ao nosso alcance de humanos e que o único processo não arbitrário, a única maneira honesta e humilde de chegar sem fantasias, a uma legítima concepção de Deus reside «na severa reflexão sobre a consciência do homem» $\left({ }^{29}\right)$. Nesta análise da consciência, descobre-se a ideia de Deus, de infinito em nós, de Pensamento absoluto e impessoal, de Espírito e Eu Transcendental, que exerce a função de universalizar e de unir o humano, realizando a essência pura da religião. Nada de transcendente à consciência corresponde, na realidade, a estas ideias e a análise permanece confinada a atributos excelentes da subjectividade humana. Não é a religião a medida do homem mas é o homem a medida da religião e, por isso, «residirá.... no humanismo de um Sócrates a mais válida e a mais pura das contribuições do Ocidente para a consciência religiosa da nossa espécie» $\left({ }^{297}\right)$. O Bem inteligível de Platão reencontrado na «luce intellectual piena d'amore» de Dante, no «amor intellectualis Dei» de Espinosa, na «Razão, irmã do Amor e da Justiça» de Antero de Quental funda «uma religião de ca-

\footnotetext{
(291) Idem, ob. cit., 36.

(292) Idem, «O Reino Cadaveroso», 55.

(293) Idem, «Considerações sobre o Problema da Cultura», 31-32.

(294) Idem, "O Reino Cadaveroso», 57.

$\left.\mathbf{C}^{295}\right)$ Idem, «Notas de Esclarecimento», 216.

${ }_{(296)}^{296}$ Idem, «Sobre Cristianismo e Cristãos», 187.

(297) Idem, ob. cit., l.c.
} 
rácter intelectualista», que unirá, no futuro, «as várias Igrejas, por que se divide a Europa», uma vez que estas se libertem definitivamente das preocupações políticas em que estão presas e a nossa razão crítica aperfeiçoe a organização social de acordo com «o anseio de amor fraterno, que é próprio da verdadeira religião». Deste duplo movimento, por um lado, das Igrejas, que se interiorizam, purificando-se do poder político e do dinheiro e realizando na consciência o ideal da religação universal, e, por outro, da técnica científica, que organiza a sociedade de acordo com esse ideal de fraternidade, eliminando o odioso das classes e arrancando, por isso mesmo, as Igrejas «à tão nefasta influência das divindades do oiro», resulta a existência do puro Deus do Espírito na sociedade humana ${ }^{298}$ ). Por isso, para Sérgio, os vícios da religião do Ocidente não estão no seu carácter intelectivo e racional, como pensa Radhakrishnan, mas na união com a política e na subordinação a César e a interesses económicos, que perverteram a interioridade religiosa, não raro mantida com autenticidade «entre os que se dizem anti-religiosos» $\left({ }^{299}\right)$.

Pressuposta esta distinção entre Religião e Política, é compreensível que Sérgio se declarasse «anticlericalista mas respeitador do catolicismo» ${ }^{30 \circ}$ ), se negasse a aceitar «o ataque jacobino à religião católica» e escrevesse que «nada nos republicanos me estarrecia tanto como o dizerem que a separação das Igrejas e do Estado era a base essencial da revolução portuguesa» $\left({ }^{301}\right)$, sem a menor consciência das reformas económicas e educacionais, que urgia realizar. "A nós, aos homens da esquerda», não convinha o regime da separação absoluta «antes de realizada a transformação profunda que arrancará a omnipotência a quem a exerce actualmente». O comportamento conservador ou retrógrado, incompreensivo e inumano da Igreja mamónica, vítima das tiranias dos cofres, anti-cristã e burguesa, "é ....um efeito, muito mais que uma causa, dos obstáculos a uma sociedade que tenha estruturação de justiça», pois o argentário, como ensina Gil Vicente, tem pervertido a Igreja ${ }^{302}$. A transformação é esperada não de uma conversão da Igreja, que «há-de permanecer no seu tergiversar sinuosissimo entre as forças capitalistas e as reclamações proletárias» mas dos «mercadores das coisas mais

$\left.{ }^{298}\right)$ Idem, ob. eit, 187-188.

C) Idem, ob. cit., 179-182.

$\left.{ }^{300}\right)$ Idem, «Prefácio da Primeira Edição» in: Idem, Ensaios I, 60; Idem, «Prefácio da Segunda Edição» in: Idem, Ensaios I, 33.

$\left(\begin{array}{l}301 \\ 302\end{array}\right)$ Idem, «Prefácio da Segunda Edição», in: Idem, Ensaios I, 35.

$\mathbf{i}^{302}$ ) Idem, ob. cit., 39. 
belas»», que são os revolucionários humanistas, de mentalidade cristã. A táctica errada da separação absoluta contrapõe Sérgio «um arranjo com a Igreja», que a vincule «à defesa indispensável do poder civil», até o dia em que se triunfe da dominação plutocrática $\left({ }^{303}\right)$. O ideal de sociedade ou Reino de Deus entre os homens, traduzido nas categorias racionais da sociologia e da economia, é confiado à força realizadora do socialismo cooperativo com a consequente anulação progressiva do papel organizador da Igreja, numa curiosa atitude paralela com o protestantismo liberal, que, no séc. XIX, propusera a secularização como emancipação da tutela da Igreja com integração simultânea desta no corpo social do Estado, exigida pelo espírito do Cristianismo. Por isso, as tendências do «Secularism» difundidas nos países anglo-saxónicos do séc. XIX eram críticas quanto à Igreja mas não necessariamente anti-cristãs $\left({ }^{304}\right)$.

O modo como Sérgio procurou 1er, de modo racional, um ideal do século em escritos religiosos e místicos, transparece da inclusão de S. Francisco de Assis e de S. ${ }^{\text {ta }}$ Teresa de Jesus no «Calendário do Seareiro», justificada por um lado, pelo facto de a Seara Nova ser uma falange moral e não uma seita limitada e estreita, de ser «um ginásio de cultura humana, de largo e generoso humanismo crítico» e, por outro lado, pela grandeza do génio moral, «essencialmente democrático, igualitário e de certo modo socialista» de S. Francisco e da «heroica e grandíssima alma» de Teresa de Ávila, criadora da literatura de introspecção e da sistemática análise psicológica.

$\mathrm{Na}$ secularização sergiana, há uma exigência de universalidade, que transcende limitações regionais a fim de ser positivamente omnicompreensiva e, por isso, «excluir S. Francisco da Seara Nova seria tão absurdo como excluir Buda, Confúcio, Zoroastro, ou o próprio Cristo». Esta exigência de universalização racional rompe todas as barreiras dos fanatismos que se degladiam e, por isso, «se não compreendêssemos Francisco e Teresa, - seríamos tão estreitos, tão sectários, tão inumanos, tão pouco nobres, como os obstinados que não compreendem (que não querem, na verdade, compreender) os pontos de vista de um Proudhon ou de um Marx».

$\left({ }^{303}\right)$ Idem, ob. cit., 40.

(3M) H.-H. Schrey, Saekaluririerung 11; H. Luebbe, Saekularisierung, Geschichte eines ideenpolitischen Begriffs (Freiburg-Muenchen 1965), 49-55. 


\section{Antonio Sérgio}

A realidade sobrenatural e súper-racional da santidade é excluída, por princípio, dada a sua transcendência, pela secularização de Sérgio, pois «a canonização para o 'seareiro' é um acidente puramente exterior, que não tira nem põe às personagens» $\left({ }^{305}\right)$ e pouco importa que os santos ou os heróis tenham realmente sido o que imaginamos ou mesmo que tenham existido, uma vez que o ideal se traduza pela imagem viva de uma pessoa ${ }^{306}$ ). Francisco e Teresa seriam duas formas superiores do ideal humanista e racionalista, pois a universalidade democrática e fraternal de um exige o «duro combate conosco próprios, já que a tendência natural do homem é para ser pequenino e para se limitar» e a introspecção do outro é um ensaio de reflexão centrípeta e de concentração racional da pessoa humana e de auto-domínio, próprio do terceiro homem, com quem Sérgio se identifica, e oposto à expansão emotiva e centrífuga e a ideais concebidos de maneira vaga, que fascinaram o homem da Primeira República ${ }^{307}$ ). Desta redução humanista do santo é solidária a afirmação de Sérgio de que «Jesus Cristo é.... uma personagem humana, muitíssimo amada mas não mais do que humana». Se lhe for atribuída uma significação divina, esta é absorvida pela dimensão humana do génio, isto é, pela universalidade do espírito e pela atitude ética e, neste sentido, é divino, como «o foi um Sócrates, um Espinosa, um Francisco de Assis, um Buda, ou (em menor escala) um Gandhi, um Tolstoi, um Romand Rolland, um Antero» $\left({ }^{308}\right)$. Identificado o Cristianismo com um ideal da razão universal e ética, Sérgio entende-o anterior uns setecentos e cinquenta anos a Cristo, pois a ideia dos primeiros profetas «é a do primeiro Deus universal e moral - a do primeiro Deus que já é concebido com uma dose suficiente de racionalismo», acima das particularidades de espaço e de tempo e das diversidades de nação e de classes e exigindo um culto interior e universalista, que igualiza os homens. Esta corrente de universalidade e de igualdade culmina com o maior dos profetas - Jesus Cristo, para quem Deus é Espírito e deve ser adorado em espírito e em verdade (João, IV, 21-24). Nesta universalidade autêntica, sem particularidades de espaço e de tempo e sem classes, está a unidade uni-

$\left(\begin{array}{l}305 \\ 306\end{array}\right)$ Idem, «Sobre o Cristianismo e os Cristãos», 209-211.

${ }^{(306)}$ Idem, «Educação e Filosofia», 149. Cf. Idem, Antologia Sociológica 258-260, 261; Idem, «Notas de Política» in: Idem, Ensaios III, 234.

$\left.{ }^{(308}\right)$ Idem, «Sobre Cristianismo e Cristãos», 192. 
ficante da Razão e a base da civilização racional, que é, por essência, cristã $\left({ }^{309}\right)$ e «um ideal que não morre» $\left({ }^{31 \circ}\right)$.

Este racionalismo estreme não é uma doutrina adoptada mas «uma qualidade inata» e, por isso, Sérgio considerava-se «absolutamente inconvertível a um dogma», «antiteológico como os mais pintados», «todo.... crítica da cabeça aos pés e.... de nascença». A estrutura mental sergiana era a do perfeito adogmático, do arritualista absoluto, de todo afastado do ímpeto católico e do anticatólico $\left.{ }^{311}\right)$. Não discutia a fé de ninguém e, como crítico verdadeiro, só discutia com críticos, isto é, com aqueles que admitiam o princípio da liberdade crítica, reconhecendo nas argumentações dos teólogos um processo incapaz de o converter à fé de uma Igreja. A haver semelhante processo, ele seria o da praxis exemplar dos fiéis, "os incêndios do amor evangélico que vivesse em labaredas nas almas deles». O exemplo consistirá no imediato empenhamento «na obra de redenção do próximo», começando por suprimir a miséria dos pobres, isto é, qualquer redenção ou libertação tem de transformar a situação concreta, social e económica, dos oprimidos. Enquanto os fiéis assim não procederem, não pode haver esperança de conversão para o incréu, pois «argumentadores facundos»» não são prova suficientemente clara da divindade de uma religião ${ }^{312}$ ). Como para um cristão, o primeiro dever de um verdadeiro estadista é dar-se conta perfeita do carácter monstruoso de uma estrutura económica, onde a injustiça é máxima. Para a análise e resolução desta situação de injustiça social, vale «a cláusula dos Evangelhos, que manda que busquemos primeiramente a tudo um ideal de moral e de justiça, já que todos os demais benefícios nos poderão vir de aí por acrescentamento» $\left({ }^{313}\right)$. É a partir do sentido social e económico que Sérgio inicia a leitura da redenção ou libertação dos textos evangélicos e, se for possível outro dimensionamento mais profundo do sentido, este jamais pode prescindir da luta contra a injustiça real, que deve caracterizar o exemplo do fiel. Na sequência do texto evangélico referido, Sérgio interpreta o «Reino de Deus» como «um regime de justiça e de amor ao próximo, ou seja, uma Socierativismo», 3 . gica, 91

$\left.{ }^{\left({ }^{10}\right)}\right)$ Idem, «Terceiro Caderno» in: Idem, Antologia Socioló-

(311) Idem, «Cartas do Terceiro Homem», 272.

(312) Idem, ob. cit., 200-203.

208.

(313) Idem, «Novo Caderno» in: Idem, Antologia Sociológica, 
dade sem divergências de interesses, sem o guerrear das classes» $\left({ }^{314}\right)$ e conclui que «os corolários sociais da doutrina cristã são da extrema esquerda» e que só pela mais profunda infidelidade ao Evangelho e por um acervo de sofismas há católicos de direita $\left.{ }^{395}\right)$. A insistência na consideração da situação económica e social do homem implica uma relevante valorização do trabalho, pois «a classe dos trabalhadores não é para mim como outra qualquer», tem uma aura de ideal, pois «é a classe para que todas devem tender, à medida que ela se eleva, que ela se educa, que ela se emancipa». O trabalho, porém, para ser emancipador, deve influir o ideal «da mais alta vida espiritual»» e da consciência máxima, deve ser um esforço de espiritualização segundo o lema da razão, haurido do Evangelho, «Deus é Espírito» $\left.{ }^{316}\right)$. E em função do trabalho que se deve organizar a educação em comunidades, ligando o aluno à vida do seu meio, ao seu torrão nativo, «num treino do intelecto que se levasse a cabo com o intuito supremo da emancipação dos homens» $\left({ }^{317}\right)$. O trabalho, assim dignificado, é eminentemente anti-coisista, liberta o homem, erguendo-o até «ao Todo-Uno, o qual não é coisa, mas Actividade» ${ }^{(18)}$ ). Por isso, o ideal democrático é exigente, está acima de nós, como o ditame de Cristo: «Sede perfeitos, como o vosso Pai do Céu é perfeito», interpretado como ideal secularizado da Razão $\left({ }^{319}\right)$. O Evangelho, se não contém uma doutrina política explícita e particularizada, inclui um critério para preferir políticas, pois apresenta-se como uma vida não ritualista nem formalista mas moral e concreta, com «o dever de trabalhar por uma organização social que nos torne possível um viver cristão» ${ }^{32 \circ}$ ) ou «O reino de Deus», «da liberdade dos homens» e «o da ascensão ao ser livre», ideal que Sérgio vê confirmado em S. Paulo (Ad Gal. IV, 3) e no Evangelho de S. Lucas (IV, 16-21) ${ }^{321}$ ). Este «Reino de Deus», que é o Reino da Justiça e da Liberdade, que é o Reino dos Desprendidos e das «boas intenções» de que fala Mestre Gil, não é o espaço dos indivíduos que se submetem às coisas e, por elas, aos homens, que detêm o poder e a posse das coisas. A ideia de

$\left({ }^{314}\right)$ Idem, «Jornada Quarta» in: Idem, Antologia Sociológica, 310-311, 330.

(315) Idem, «Relanços de Doutrina Democrática», 170-171.

(316) Idem, ob. cit., 174.

(317) Idem, "Cartas do Terceiro Homem», 254.

(318) Idem, «Migalhas de Filosofia», 211.

$\left({ }^{319}\right)$ Idem, «Diálogos de Doutrina Democrática», 53.

$\left(\begin{array}{l}32 \circ \\ 321\end{array}\right)$ Idem, "Cartas do Terceiro Homem», 199.

$\left.{ }^{321}\right)$ Idem, ob. cit., 329. 


\section{Neo-iluminismo Filosófico}

Epitecto de que «aquele que se submete aos homens - é porque primeiro se submeteu às coisas», tem, para Sérgio, a mesma inspiração moral, que ressalta do Evangelho, ao afirmar pela pena de S. Mateus, que «onde está o teu tesouro, aí está o teu coração» e não se pode servir a Deus e ao dinheiro (Mat., VI, 21,24) $\left({ }^{322}\right)$.

Este reino social de justiça e de liberdade aflora ao texto das declarações dos direitos humanos, que não são simples consequências do evoluir histórico mas produtos da Razão do homem e da sua capacidade inata, para subir ao nível do universal e do eterno, com desprendimento do biológico e da obsessão do sensível. Interpretando a palavra «Deus» no sentido deste princípio universalista de justiça e de liberdade, Sérgio aceita o modo de dizer de A. Herculano, segundo o qual os direitos humanos e Deus constituem verdades da consciência humana, sintetizadas no direito de liberdade efectiva com o complexo das questões sociais e políticas $\left({ }^{323}\right)$. Este modelo da Razão ética, social e jurídica serve de cânon interpretativo dos textos neotestamentários citados, referentes ao «Reino de Deus» e, por esta via, Sérgio reactualizou aquele sentido de Aufklaerung, que se identificou com o sistema universal dos direitos humanos $\left({ }^{324}\right)$.

VI. Sérgio confrontou frequentemente o seu pensamento com textos bíblicos paradigmáticos mas não encontrou, na sua terra, da parte da Teologia, um interlocutor válido, que falasse a sua linguagem. Do ponto de vista filosófico, nenhuma possibilidade de diálogo nasceu de qualquer esforço comum de se pensar o homem fora do paradigma coisista e de se conceber a transcendência do Ser a partir da essência da liberdade.

Num breve relance sobre o panorama teológico europeu, pode afirmar-se que uma dissimetria contrastante opôs a Teologia Evangélica à Teologia Católica, pois enquanto a primeira incluiu na sua Hermenêutica os problemas fundamentais da Aufklaerung e do Idealismo, a segunda restaurou a Escolástica e, com ela, modelos de pensamento medieval flagrantemente estranhos ao espírito moderno, se exceptuarmos o fenómeno passageiro da Escola Católica de Tuebingen, cedo reduzida à inanição pela condenação do Modernismo. Esta situação conservadora é expressa, nestes termos, por K. Rahner em 1970: «....A situação da Teologia Católica, ainda há trinta

$\left(\begin{array}{l}322 \\ { }^{322}\end{array}\right)$ Idem, ob. cit., 331-332.

( $\left.{ }^{323}\right)$ Idem, «Relanços de Doutrina Democrática», 181-182.

$\left({ }^{324}\right)$ M. B. Pereira, «Iluminismo e Secularização», 473. 
anos, era a de um sistema fechado» $\left({ }^{325}\right)$. O perigo, que perseguia esta situação da Teologia, não era só a de um divórcio relativamente às experiências fundamentais do homem moderno mas ameaçava a unidade de sentido da própria consciência religiosa, ferida de divisão interna em si mesma. Por isso, impôs-se à Teologia Católica a dupla tarefa de assumir, na sua seriedade, os problemas do pensamento moderno desde a Aufklaerung, elaborando-os criativamente, e de, por este esforço de compreensão, patentear possibilidades novas da existência cristã. $\mathrm{O}$ exemplo de J. Maréchal, que realizara uma interpretação de Kant, revelando a intenção ontológica profunda da sua filosofia crítica, frutificou em pensadores católicos, como, v. g., G. Siewerth J. B. Lotz, M. Mueller, B. Welte, K. Rahner, que «des-medievalizaram» o conceito de Ser, em diálago crítico com expoentes do pensamento europeu, como Kant, Hegel, M. Heidegger, etc., na tentativa de transpor o fosso que separava a tradição das exigências novas e originais da Modernidade $\left(^{326}\right)$. E, apesar de tudo, salutar que, duzentos anos após o "século das luzes», se reconheça na positividade e na seriedade da problemátcia da Aufklaerung o acesso indispensável ao mundo contemporâneo. Além do interesse pela problemática kantiana, o pensamento de Hegel, Schelling, Feuerbach, M. Heidegger, E. Bloch, é já ponto crítico de partida de posições contemporâneas da Hermenêutica Teológica, que pretendem tornar-se inteligíveis em categorias modernas $\left({ }^{327}\right)$.

$\mathrm{O}$ conceito dialéctico de experiência de Hegel aparece em K. Rahner sob a afirmação de que todo o encontro consigo mesmo é mediado pelo outro, não em sentido coisista mas pessoal, e implica, portanto, uma teoria da intersubjecti-

$(325)$ -Zuerich-Koeln 1970), 82.

K. Rahner, Schriften zur Theologie, IX (Einsiedeln-

(32a) M. B. Pereira, Ser e Pessoa - Pedro da Fonseca - 1,0 Método da Filosofia (Coimbra 1967), 59-74; Idem, Originalidade e Novidade em Filosofia. A propósito da Experiência e da História (Coimbra 1977), 32-33.

$\left.{ }^{327}\right)$ Cf. Hans Kueng, Menschwerdung Gottes, Eine Einfunehrung in Hegels Theologiches Denken als Prolegomena zu einer kuenftigen Christologie (Freiburg-Basel-Wien 1970); W. Kasper, Das $A b$ solute in der Geschichte, Philosophie und Theologie der Geschichte in der Spaetphilosophie Schellings (Mainz 1965); M. Xhaufllaire, Feuerbach et la Théologie de la Sécularisation (Paris 1970); R. Schaeffler, Froemmigkeit des Denkens? Martin Heidegger und die Katholische Theologie (Darmstadt 1978); Idem, Was duerfen wir hoffen? Die Katholische Theologie der Hoffnung zwischen Blochs utopischem Denken und der ref or matorischen Rechfertigungslehre (Darmstadt 1979). 
vidade e da comunicação, que Rahner pressupõe na sua tese da unidade do amor do próximo e do amor de Deus ou da sua recíproca implicação na experiência pessoal do outro ou de Deus $\left({ }^{328}\right)$. Esta intersubjectividade comunicativa é dinâmica, é uma interacção ou um processo temporal social, que, através das possibilidades concretas de vida futura para o próximo em que se empenha, visa o Futuro Absoluto ou o Deus Pessoal, a Super-Acção na interacção humana ${ }^{329}$ ). Daí, o conceito de homem de K. Rahner, radicalmente intersubjectivo e comunicante, indefinidamente aberto como «ouvinte da palavra» e destruidor de um hermetismo da razão, que, sem sensibilidade para o mistério, hipostasiasse os seus ideais $\left({ }^{330}\right)$.

Desde o Iluminismo, a razão científica e filosófica construiu teorias que se propunham explicar a função da religião dentro do processo histórico-evolutivo da humanidade, não passando a teologia de uma forma reflexiva da consciência religiosa, útil, pela sua funcionalidade, a determinado grau de evolução do homem, mas plenamente explicável por uma Meta-teoria, que explica histórica e socialmente o aparecimento da teologia, racionalizando-lhe plenamente os fundamentos e as razões da sua existência histórica. Numa radicalização dos ideais do Iluminismo, K. Marx privilegiou um conceito de praxis, que revolucionasse o estado da evolução da espécie humana, alterando profundamente os mecanismos vigentes da sociedade estabelecida, em todas as suas dimensões, sobretudo na dimensão da consciência, cuja mudança radical acarretaria a anulação da consciência religiosa e, com ela, a da Teologia. Neste desenvolvimento histórico e sócio-político, situa-se a Teologia Política de J. B. Metz $\left.{ }^{331}\right)$, que assenta no mundo «hominizado», construído pelo homem em luta com as suas condições naturais e dentro de um projecto de futuro, que ele quer e pode ser. Ao homem na sua história e nas suas possibilidades abertas, ao processo de auto-constituição do género humano ou de socialização se devem referir as expressões teológicas, que pretendam interpretar experiências his-

$\left.C^{328}\right)$ K. Rahner, «Ueber die Einheit von Naechsten-und Gottesliebe» in: Idem, Schriften zur Theologie, VI (Einsideln-Zuerich-Koeln 1965), 227-298.

$(329)$ Idem, ob. czt., 256.

(33o) K. P. Fischer, Der Mensch als Geheimnis, Die Anthropologie Karl Rahners (Freiburg-Basel-Wien 1973), passim.

${ }^{(331)}$ J. B. Metz, Zur Theologie der Welt (Mainz-Muenchen 1969); Idem, «Die Zukunft des Glaubens in einer Kominisierten Welt», in: Idem; Weltverstaendnis im Glauben (Mainz 1965), 45-62. 
tóricas da humanidade e acontecimentos históricos relevantes ou, por outras palavras, a Teologia está necessariamente referida à sociedade. Isto significa, portanto, que os processos sociais, económicos e políticos não se limitam ao seu sentido imediato restrito mas têm uma pluridimensionalidade e uma significação mais ampla, que funda o seu estudo interdisciplinar. Por isso, a Teologia, ao exprimir-se no sistema das novas categorias hauridas do mundo histórico-social, realiza a outra semântica profunda do social e do político. O próprio facto da consciência falsa é ininteligível sem a consciência verdadeira e pressupõe outras possibilidades humanas concretas, que não as das estruturas sociais existentes, onde as experiências de injustiça e de sofrimento se acumulam.

A tradição teológica conservou a ideia da possibilidade e da realidade da consciência falsa e da cegueira social e, por isso, atribuiu ao "Kerygma» a função de denunciar a consciência falsa e de libertar o homem para a verdadeira vida. Ao realizar a hermenêutica das suas proposições, uma Teologia, que aceita a sua essencial referência à sociedade, empenharse em esclarecer como é que se realiza o trânsito da consciência falsa para a verdadeira, sem perder o sentido da auto-crítica, pois a Teologia jamais se pode arrogar a consumação definitiva da consciência verdadeira, visto não ignorar que também ela, pela sua condição humana, sofre das limitações da sociedade, de que tenta ser consciềncia crítica $\left({ }^{3 \mathrm{~S} 2}\right)$. Não sai da história nem abandona o mundo e, por isso, a compreensão teológica torna-se praxística, mediante a eliminação dos impedimentos da personalização e a transformação das relações sociais, isto é, encerra em si o momento essencial da ortopraxis. O fundamento desta crítica das distorções da consciência falsa e das ilusões do eu não se esgota em qualquer tempo presente mas é sempre eminentemente futuro, agindo numa história aberta e inacabada, em que o novo é a categoria central. Neste caso, o que define a existência, é a superação do presente e a descoberta do novo, ainda não pensado nem experienciado, capaz de conferir ao passado o seu sentido definitivo. A antecipação de um futuro, que o homem não domina nem produz, e o protesto contra a facticidade histórica rasgam possibilidades ao discurso sobre Deus, de que apenas negativamente se fala, como do Senhor do Futuro e do Ser que chega. Este discurso não é teórico mas essencial-

(.*32) Peukert, Wissenschaf theorie, Handlungstheorie, Fundamentale Theologie, Analysen zu. Ansatz und Status theologischer Theoriebildung (Frankfurt/M. 1978), 55-56. 
mente mediado pela acção, que muda o fáctico e o estabelecido e restitui a liberdade perdida, de tal modo que o fim do discurso teológico é a acção transformadora, cujo primado impede o pensamento de se perverter no quietismo das especulações $\left({ }^{333}\right)$. Todo o acontecimento verdadeiramente salvifico é interpretado não como simultaneidade pura do momento presente mas como antecipação da novidade do futuro e possibilidade de mudança do presente. Esta experiência pressupõe uma estrutura fundamental da história marcada pelo futuro, pela esperança e apela a uma compreensão da acção motivada, no seu imperativo metanoético, pela urgência do reino que chega e prepara um conceito teleológico de Deus. A relevância do passado, que justifica o valor do recordar, significa, para o presente, a sua transformação, pois só relativamente ao futuro é que os acontecimentos históricos revelam o seu significado pleno e rigoroso. A comunicação com o passado coincide com a sua acção libertadora da injustiça e do domínio do mundo hermético e opressor do presente e, por isso, a relação à sociedade concreta, privilegiada pela Hermenêtica Filosófica e Teológica, só restabelecendo a leitura escatológica do passado, pode fundar um discurso ao mesmo tempo comemorativo e libertador e patentear a latente interacção dos homens entre si e com Deus. Pela dimensão escatológica, a recordação autêntica do passado contribui para a libertação do presente e, neste caso, a unidade do sentido histórico organiza-se à volta da categoria do novo, concebida por E. Bloch como o «nervo do recto conceito de história» e, sob a forma de um «novo melhor», como a inspiração mais profunda da filosofia $\left({ }^{334}\right)$ e interpretada por teólogos, atentos aos sinais da sociedade e da história, no sentido do Ea/axav divino ou do Futuro Absoluto $\left({ }^{335}\right)$.

Este novo estilo teológico de pensar manifesta incondicional solicitude pelo homem histórico concreto, concebido não de modo coisista mas como uma liberdade a realizar-se, e poderia satisfazer a invencível lógica das acções da ortopraxis solicitada por A. Sérgio e a que o incréu seria sensivel. A diferença e a alteridade experienciadas na intersubjectividade e na solidariedade humanas não são categorias da realidade coisista mas também não se eliminam pela elevação

1626.

("*) H. Peukert, ob. cit., 67.

$\left.C^{M}\right)$ E. Bloch, Das Prinzip Hoffnung, IIP (Frankfurt/M. 1968),

$\left.{ }^{335}\right)$ Cf. E. Schillebeeckx, Gott - Die Zukunft des Menschen, Uebers. (Mainz 1969); K. Rahner, Zur Theologie der Zukunft (Muenchen 1971), 177-228. 
ao ideal universal e abstracto do espírito. Esta resistência à redução a uma ideia é o indício de uma nova realidade, que, não sendo matéria coisificada, transcende a imanência da consciência, revelando-a excêntrica e não concêntrica, extática e não egóide, historicamente expectante do novo e não motor imóvel, eterno no seu ideal auto-suficiente. Isto equivaleria a iniciar com Sérgio o diálogo filosófico, que a vida lhe negou, sobre problemas já formulados pelo génio iluminista de Kant: "Que posso eu saber? Que devo eu fazer? Que posso eu esperar?» (336), resumidos numa pergunta global: "Que é o homem?» $\left.{ }^{337}\right)$. Na imanência da consciência, que, pela interiorização ou concentração sergiana, regressa a si mesma, como autonomia plena mas abstracta e egológica, ou na liberdade que se transcende realmente, querendo a liberdade de outrem, numa relação real concreta de sociabilidade irredutível a uma ideia, jogar-se-ia a essência do homem e do reino da liberdade. A experiência da cooperação solidária e fraterna conduz à descoberta, no homem, da relação, inscrita nas profundas raízes do seu ser - relação real sem ser coisista, bem distante da relação pensada na imanência de um Eu Absoluto.

Repensar criticamente a razão crítica de Sérgio é, finalmente, perguntar se a superação do coisismo está suficientemente assegurada no Eu impessoal ou se este cume supremo da Razão, dada a anulação de todo o traço de personalidade, não passa de um modelo coisista interiorizado e idealizado, é interrogar-se sobre a instância última, monológica ou dialógica, da moralidade, é perguntar se a liberdade não será distinta da ideia de liberdade e, por essência, plural ou se continuará intacta na imanência da consciência apesar de simplesmente pensada, é inquirir sobre o estatuto originário ou derivado da Razão, é interrogar o pre-racional e o ante-predicativo da nossa experiência quanto ao seu papel na génese da Razão ou se é lícito hipostasiar a estrutura eterna desta, é perguntar se o tempo da história humana é apelo que, na sua urgência, se deve ouvir ou reino instável a dominar e a subsumir sob leis idealmente pre-dadas.

Comemorar Sérgio não é repeti-lo, é ensaiar, sem a hybris da consumação, o esclarecimento do subsolo da sua razão, volvendo mais crítica a sua crítica. ${ }^{(*)}$

(**) I. Kant, Kritik der reinen Vernunft, hrsg., v. W. Weischedel (Wiesbaden 1956), 677.

( $\left.{ }^{\mathrm{MT}}\right)$ Idem, Schriften zur Metaphysik und Logik, hrgs., v. W. Weischedel (Wiesbaden 1958), 447-448. 